\title{
Poundbury Camp in context - a new perspective on the lives of children from urban and rural Roman England
}

Article

Accepted Version

Rohnbogner, A. and Lewis, M. (2017) Poundbury Camp in context - a new perspective on the lives of children from urban and rural Roman England. American Journal of Physical Anthropology, 162 (2). pp. 208-228. ISSN 1096-8644 doi: https://doi.org/10.1002/ajpa.23106 Available at https://centaur.reading.ac.uk/67760/

It is advisable to refer to the publisher's version if you intend to cite from the work. See Guidance on citing.

To link to this article DOI: http://dx.doi.org/10.1002/ajpa.23106

Publisher: Wiley

All outputs in CentAUR are protected by Intellectual Property Rights law, including copyright law. Copyright and IPR is retained by the creators or other copyright holders. Terms and conditions for use of this material are defined in the End User Agreement.

www.reading.ac.uk/centaur 
Central Archive at the University of Reading

Reading's research outputs online 
Accepted by the American Journal of Physical Anthropology on 16/09/2016

\section{Poundbury Camp in Context - a new perspective on the lives of children from urban and rural Roman England}

Rohnbogner, Anna and Lewis, Mary Elizabeth

University of Reading, UK

Department of Archaeology, School of Archaeology, Geography and Environmental Science, University of Reading, Reading, RG6 6AB, UK

a.j.rohnbogner@reading.ac.uk

Abbreviated title: Poundbury Camp in Context - non-adult health in Roman Britain

Keywords: stress - inequality - metabolic disease - tuberculosis - thalassaemia Romanisation - migration

This research was funded by an AHRC PhD studentship. 


\section{ABSTRACT}

\section{Objectives}

Our current understanding of child morbidity in Roman England is dominated by studies of single sites/regions. Much of the data are derived from $3^{\text {rd }}-5^{\text {th }}$ century AD Poundbury Camp, Dorchester, Dorset, considered an unusual site due to high levels of non-adult morbidity. We have little understanding of children in rural areas, and whether Poundbury Camp was representative of Romano-British childhood.

\section{Materials and Methods}

The study provides the first large scale analysis of child health in urban and rural Roman England, adding to the previously published intra-site analysis of non-adult palaeopathology at Poundbury Camp. Age-at-death and pathology prevalence rates were reassessed for 952 non-adults (0-17 years) from five major urban, six minor urban and four rural sites $\left(1^{\text {st }}-5^{\text {th }}\right.$ century AD). The data were compared to the results from 364 non-adults from Poundbury Camp.

\section{Results}

Rural sites demonstrated higher levels of infant burials, and greater prevalence of cribra orbitalia in the 1.1-2.5 years (TPR 64.3\%), and 6.6-10.5 year cohorts (TPR 66.7\%). Endocranial lesions were more frequent in the minor urban sample (TPR 15.9\%). Three new cases of tuberculosis were identified in urban contexts. Vitamin D deficiency was most prevalent at Poundbury Camp (CPR 18.8\%), vitamin C deficiency was identified more frequently in rural settlements (CPR 5.9\%).

\section{Discussion}

The Poundbury Camp data on morbidity and mortality are not representative of patterns in Roman England and other major urban sites. Rural children suffered from a distinct pattern of diseases of deprivation, prompting reconsideration of how Romano-British land management affected those at the bottom of the social hierarchy. 
The study of child skeletal remains in bioarchaeology has become an increasingly popular way to measure the impact of environmental stress in the past (Perry, 2005; Lewis, 2007; Halcrow and Tayles, 2008; 2011; Gowland, 2015). In England, while more comprehensive studies of children living in medieval and post-medieval societies emerge (Lewis, 2016; Newman and Gowland, 2016), our understanding of child health during the Roman period, a time of major social upheaval, is still little understood. The studies that exist are coloured by reliance on a limited number of skeletal assemblages (Redfern, 2007; 2008; Lewis, 2010; 2011; 2012; Redfern et al., 2012). In contrast to later periods, documentary evidence relating specifically to Roman Britain is scarce, and any historical evidence for weaning, child rearing, education, health, and employment of children comes mainly from the Mediterranean. Arguments surrounding the extent to which Roman culture was adopted by native populations are still on-going, with ideas of 'Romanisation', whether considered imperially-imposed acculturation or native emulation, gradually being replaced by more complex models such as creolisation (Webster, 2001; Mattingly, 2006).

Further, extensive studies that integrate skeletal evidence with archaeological and environmental data are limited in Roman archaeology due to cremation as the predominant burial rite during the $1^{\text {st }}$ and $2^{\text {nd }}$ centuries AD. The shift in funerary rites from mostly cremation to inhumation during the $3^{\text {rd }}$ century AD means that we are often, but not exclusively, limited to the later periods of Roman rule (ca. AD 250-410) for osteological studies. Although the majority of our skeletal data are derived from urban sites, many questions still remain about the extent of urbanisation, and the impact it had on the health of the native population. Some argue that the Romans brought about improvements in sanitation and living conditions (Mattingly, 2006: 323), with planned Roman cities boasting marbled surfaces and flowing water, providing extensive facilities for the comfort and health of the inhabitants (Morley, 2005). Diametrically opposed is the view that urbanisation widened the divide between the rich and the poor, with many suffering hardships of poverty, social unrest, and subservience to the conquering population. Redfern and Roberts (2005) concluded that the pathology and mortality levels in seven urban sites in Roman Britain pointed to unsanitary and squalid living conditions. They cite environmental evidence from Poultry Lane in London as indicating household refuse built-up in yards, wells were contaminated by the close proximity of pigs and chickens, and outdoor latrines were dug into kitchen spaces. These conditions, in combination with an increased migrant population and the introduction of pubic bath houses, led to a decline in the sanitary conditions in these crowded, built-up areas in England (Redfern, 2008). Studies comparing the prevalence of pathology in urban 
and rural settlements in late Roman England have demonstrated that living in the countryside also negatively affected its residents (Pitts and Griffin, 2012; Redfern et al., 2015). While important in their contribution, this evidence is limited in its scope by reliance on previously published data, the lumping of non-adults into a single age bracket (Redfern and Roberts, 2005; Pitts and Griffin, 2012), a focus only on adult remains (Roberts and Cox, 2003; Griffin and Pitts, 2011) or the study if a single site or region (Lewis, 2011; Redfern et al., 2015).

The children excavated from the late Romano-British cemetery of Poundbury Camp, Dorset $\left(3-5^{\text {th }}\right.$ century AD) represent the largest single sample of child skeletons from this period $(n=364)$. They were first analysed in 1993 when some unusual cases of infection and trauma were identified (Molleson and Cox, 1988; Farwell and Molleson, 1993; Molleson, $1989 ; 1992 \mathrm{a}, \mathrm{b})$. As is the case with many major Romano-British sites, the Poundbury Camp osteological report pre-dated major advances in child palaeopathology. Re-analysis of the child remains revealed new evidence for rickets, scurvy and trauma (Lewis, 2010), as well as identifying the first cases of non-adult tuberculosis in Roman England (Lewis 2010; 2011). Thalassaemia was also identified for the first time in the palaeopathological record, through characteristic rib lesions, uncovering ill-health in children born to migrant parents (Lewis, 2012). The prevalence of pathology at this site was surprising in its similarity to that seen in post-medieval samples, suggesting the severity of the impact of urbanisation, cultural practices and perhaps conquered existence was radically affecting child health and survival. Lewis (2011) stated that without comparatively analysed child data from other urban and rural sites, the extent to which this pattern reflected the experience of children under Roman rule in England could not be assessed. There are reasons to believe that Poundbury Camp was exceptional in its extent of pathology. For example, the inhabitants of the civitas capital of Durnovaria buried their dead at Poundbury Camp in a managed 'Christian-style', witness to a 'Romanised' elite at the site (Sparey-Green, 2004). Incoming Christian beliefs may have profoundly shaped daily conduct at the site, dictated dietary practices for women and children, and impacted on their nutritional status and overall well-being (Cool, 2006; Lewis, 2010). In addition, the foundation of churches would have dictated land distribution and management, as well as the lifestyles of the local population throughout western areas of Roman Britain (Jones, 1982; Frend, 1992; Faith, 1997:16-8; Whittaker and Garnsey, 1997:301; Esmonde Cleary, 2004). This study aims to rectify this deficiency in our knowledge about the true nature of the lifestyle and lived reality of the children of Roman England by presenting new data on the analysis of 953 individuals from 15 urban and rural sites in Roman England. Through this unique dataset, we will explore the extent to which the 
late Romano-British villa economy affected the peasantry, and whether the urban environment was in fact as taxing on child health as the Poundbury Camp data would suggest.

\section{MATERIALS AND METHODS}

Demographic and palaeopathological data for the 364 Poundbury Camp (3-5 $5^{\text {th }}$ century) non-adults were compared to 953 non-adults examined from 15 urban and rural early and late Romano-British sites from across England, dating from the $1^{\text {st }}-5^{\text {th }}$ century AD (Table 1, Fig.1). In accordance with Pitts and Griffin (2012) sites were divided into major urban (coloniae, civitates), minor urban (nucleated/small towns) and rural settlements (villages, farmsteads, villa estates). 'Major urban' sites were defined as large legal and administrative planned settlements, including a grid street layout, public buildings, a forum and a spiritual focus (Wacher, 1974; Burnham and Wacher, 1990; Millett, 1990; Laurence et al., 2011). The characteristics of 'minor urban' (un-)walled settlements spark ongoing debates. It is generally agreed however that these display some urban aspects, such as evidence for town planning and a market to facilitate local trade, albeit on a smaller scale (Hingley, 1989; Burnham, 1993; 1995; Millett, 1995; Wilson, 2011). Rural sites were defined as undefended farmsteads, villages or villa estates with a predominantly agricultural focus (McCarthy, 2013). Depending on their location, rural sites would have exhibited varying economic and socio-cultural dependence on nearby towns (Laurence et al., 2011; White, 2014). However, their agricultural focus still rendered them as rural in character and urbanisation of the countryside as seen in Italy was not apparent in Roman Britain (Laurence, 2011). Current models on life in the Romano-British countryside consider villa economies as estates managed by landowners, with a peasant population that cultivates the land as tenants or freeholders, living either on the estate itself, or the surrounding villages (Taylor, 2001; Mattingly, 2006; McCarthy, 2013; Breeze, 2014). The terms 'urban' and 'rural' describe a type of settlement rather than geographic location, however there is growing awareness of the difficulty in classifying the type of Romano-British settlements (Mattingly, 1997; Millett, 1999; Burnham et al., 2001; Millett, 2001; Pearce, 2008; Rogers, 2011). Not all urban cemeteries would have contained those living and dying exclusively within these large settlements, as many individuals may have been derived from the "urban periphery" (Goodman, 2007:1-2), or represent rural migrants (Griffin and Pitts, 2012; Redfern et al., 2015). [Figure 1 here; Table 1 here]. 
Age-at-death was estimated using Moorrees et al.'s (1963a,b) standards for deciduous and permanent tooth formation using Smith's (1991) tabulation. When the dentition was absent, age was assigned based on maximum diaphyseal length and epiphyseal fusion (Scheuer and Black, 2000). Perinatal ageing used Scheuer et al.'s (1980) diaphyseal length regression formulae which was considered the most appropriate standard as they are derived from English neonates. Non-adults were then assigned to one of seven age groups: perinate ( $<42$ weeks gestation), 0.0-1.0 years, 1.1-2.5 years, 2.6-6.5 years, 6.6-10.5 years, 10.6-14.5 years and 14.6-17.0 years. The cut-off point of 17.0 years was determined by the completion of the root of the third molar (Rc), providing a mean age of 16.9 years old (Moorrees et al., 1963a). Age groups correspond with important developmental milestones in childhood such as infancy or adolescence, allow for direct comparison with the Poundbury Camp data, and limit observer bias.

In order to assess levels of stress caused by infections of a non-specific nature and/or localised trauma, sub-periosteal new bone formation and endocranial lesions were recorded. Sub-periosteal new bone formation was recorded as healed or active in accordance with Ortner (2003). Lesions were evaluated in consideration with any other pathological lesions present in any one individual to prevent over-recording (Lewis and Roberts, 1997; Weston, 2008). As we are yet to be able to differentiate a traumatic or infectious origin of subperiosteal new bone formation from healthy regular bone growth in the youngest individuals (Lewis, 2007), perinates and infants were removed from analysis for new bone formation. Endocranial lesions were recorded according to Lewis (2004). Fine deposits of fibre bone around the cruciate eminence of the occipital bone were discounted when seen in the infants as they may result from normal cranial development (Lewis, 2004). The overall disease state of the individual was taken into account, as endocranial lesions that were observed in diagnoses for tuberculosis, and vitamin $\mathrm{D}$ or $\mathrm{C}$ deficiencies, form part of a wider systemic infectious or metabolic response.

As evidence for non-adult tuberculosis (TB) in the Roman period has only recently been identified (Lewis, 2012; Clough and Boyle, 2010), special attention was paid to the presence or absence of this condition in the re-analysed material. Tuberculosis was diagnosed in the presence of lytic lesions in the spine in combination with visceral rib lesions (Pfeiffer, 1984; 1991; Roberts and Buikstra, 2003), supported by the presence of widespread new bone formation (Santos and Roberts, 2001). Pott's disease (spinal collapse) was considered pathognomonic (Resnick and Kransdorf, 2005:758-63). 
Acquired haemopoietic conditions such as iron deficiency anaemia were assessed through the presence of cribra orbitalia and porotic hyperostosis, scored according to StuartMacadam (1991). Macroscopic assessment of cribra orbitalia is influenced by preservation and the porous nature of non-adult bone which may mimic or obscure subtle lesions. Therefore, Grades 1 (capillary-like impressions), and 2 (scattered fine foramina) were discounted to prevent over-recording. Given recent research into the aetiology of cribra orbitalia, lesions are interpreted as a general indicator of poor nutritional status, as the result of a lack of fresh vegetables and meat, a high pathogen load, parasitic infections, or diarrhoeal disease (Holland and O’Brien, 1997; McIlvaine, 2013; Mahmud et al., 2013). Healed lesions were distinguished from active lesions following Mensforth and colleagues (1978). In addition, evidence for the genetic anaemia thalassaemia, was assessed based on the presence of costal osteomas or 'rib-within-a-rib' (Lawson et al., 1981a,b), osteopenia and generalised cortical thickening, in addition to cribra orbitalia and porotic hyperostosis (Ortner, 2003:364-6, Tyler et al., 2006, Lagia et al., 2007; Lewis, 2011).

Vitamin D deficiency (rickets and osteomalacia) was identified following the criteria of Ortner and Mays (1998), Ortner (2003) and Brickley and Ives (2008). The presence of rickets in archaeological populations allows us to make inferences on dress, childcare practices, climate and environmental pollution (Lewis, 2002:55; 2010; Mays et al., 2006; Brickley and Ives, 2008: 263; Pettifor, 2014). More recently, Snoddy et al. (2016) considered the extraskeletal effects of vitamin D deficiency, which increase the risk for autoimmune and infectious diseases, demonstrating that the effects of rickets within a population extend beyond brittle bones. Vitamin C deficiency (scurvy) was scored according to Brickley and Ives (2006) and the 'Ortner criteria' for lesions on the skull and metaphyseal areas of the long bones (Ortner and Ericksen, 1997; Ortner et al., 1999; 2001; Crandall and Klaus, 2014; Stark, 2014). Stark (2014) describes the presence of scurvy as a vehicle for exploring food insecurity, preferential feeding and subsistence economy. Co-occurrence of metabolic disease is likely, and non-adults may suffer from both vitamin C and D deficiency, or one of the former coupled with a haematopoietic condition (Brickley and Ives, 2008). However, since vitamin $\mathrm{D}$ and $\mathrm{C}$ interaction is inhibitory, but the haemorrhaging process unaffected, scurvy is likely to mask the expression of vitamin D deficiency (Schattmann et al., 2016). In order to differentiate co-occurrence, complete skeletons are necessary which the archaeological record cannot always provide. It was decided that individuals that exhibited inconclusive lesions attributable to either or both metabolic diseases were grouped to avoid skewing of the metabolic disease data. Discussion of individuals with potential co-occurrence is not included 
here. All individuals with a diagnosis of trauma, metabolic disease, or tuberculosis were sought to be examined radiographically, which was not possible for the Cannington and Trentholme Drive archives.

In order for a systemic pathological condition to be considered absent and an individual to be included in the true and crude prevalence rate calculations, the tibiae, cranial vault and thoracic spine needed to be observable. Differences between the four groups were assessed using the $4 \times 2$ chi-square statistic at $99.5 \%$ confidence $(p<0.005)$ when percentages demonstrated big differences between the groups. Differences in the frequency of skeletal pathologies and age-at-death across the site types were used to assess the association between lesion presence or absence and survival into later childhood. Young non-adult, and particularly infant bone has complex properties which include rapid remodelling and masking of pathologies, and insufficient time for a disease to act on the skeleton before death. Rather than comparing infants to older non-adults with all skeletal pathologies merged, a broader age group of 0-5 years was used to buffer against these limitations, comparing lesion frequency in young non-adults aged 0-5 years to older non-adults aged 6-17 years. Differences in the frequencies of pathology according to age-at-death were assessed using Fisher's exact test set at $99.5 \%$ confidence $(\mathrm{p}<0.005)$.

\section{RESULTS}

\section{Age-at-death}

The age-at-death distribution in the Romano-British samples is provided in Table 2 (Fig 2). The number of perinates was low at Poundbury Camp compared to other sites, but did not differ statistically $\left(X^{2}=4.78\right.$, d.f. $\left.=3\right)$. However, the number of infant remains (under 1 year old) was significantly higher for rural sites at $31.3 \%\left(X^{2}=17.32, \mathrm{p}<0.005\right.$, d.f. $\left.=3\right)$. The rural sample has high numbers of intramural infant burials. All 48 burials from Catsgore and Bradley Hill in Somerset were recovered from within the settlement boundaries, resulting in high numbers of intramural infant burials in the rural cohort. There is a dip in the number of 6.6-10.5-year olds in the rural sample to $5.2 \%$, although the rate is not significantly lower than at Poundbury Camp and other urban settlements $\left(X^{2}=7.76\right.$, d.f. $\left.=3\right)$. Interestingly, the ageat-death distribution at Poundbury Camp is different to the rest of the urban sites in the study and does not directly compare to other major urban sites. [Table 2 here; Figure 2 here].

\section{Pathology and age-at-death}


The major urban, minor urban and rural groups show greater lesion frequency in older non-adults, whereas Poundbury Camp is characterised by an inverse pattern. Statistically significant differences in the distribution of skeletal pathologies and age-at-death were found in the non-adults from minor urban $\left(X^{2}=16.94, \mathrm{p}<0.001\right.$, d.f. $\left.=2\right)$ and rural sites $\left(X^{2}=14.69\right.$, $\mathrm{p}<0.001$, d.f. $=2$ ) (Table 3). Young non-adults as non-survivors exhibited significantly lower lesion frequencies than older non-adults at these sites. [Table 3 here].

\section{Indicators of non-specific stress}

The prevalence of endocranial lesions was significantly higher in the minor urban cohort at $15.9 \%$ compared to Poundbury Camp and all other sites types $\left(X^{2}=21.96, p<0.001\right.$, d.f.=3) (Table 4). There was no statistical difference in the distribution of sub-periosteal new bone formation between all four samples $\left(X^{2}=7.2\right.$, d.f. $\left.=3\right)$. Rural non-adults exhibited equal frequencies of active and healed lesions at $2.1 \%$, whereas active new bone formation was more frequently observed at Poundbury Camp $(2.1 \%$, healed $0.7 \%)$ and both major urban (active $4.9 \%$, healed 3.8\%) and minor urban sites (active 3.9\%, healed 2.0\%) (Table 5). [Table 4 and 5 here].

\section{Tuberculosis}

At Poundbury Camp, 165 individuals were assessed for tuberculosis, with a total of $10(6.1 \%)$ suspected cases. These include three cases $(1.8 \%)$ of pulmonary infection, five individuals $(3.0 \%)$ with lesions possibly indicative of tuberculosis and with pulmonary disease as a differential diagnosis, and two children (1.2\%) aged 10.6-14.5 years old with lesions strongly suggestive of tuberculosis (Table 6). Six new cases of probable and possible tuberculosis were identified in the current study (Table 7), with all three probable cases from major and minor urban sites (Figs. 3-5). [Figure 3, 4, 5 here]. There are still only few cases of probable and possible non-adult tuberculosis to make meaningful statistical comparisons between the sites types. However, a trend is apparent in higher rates of pulmonary infection in major urban sites, compared to Poundbury Camp, as well as minor urban and rural sites (Table 6). [Table 6 and 7 here].

\section{Haematopoietic conditions}


The true prevalence of cribra orbitalia was statistically significantly higher at Poundbury Camp compared to the both the urban and rural sites types, at $38.5 \%\left(X^{2}=29.88\right.$, $\mathrm{p}<0.005$, d.f.=3) (Table 8). Within the 1.1-2.5 and 6.6-10.5 year age groups, rural non-adults display higher rates at TPR $64.3 \%$ and TPR $66.7 \%$ respectively (Fig. 6). Small sample sizes in the rural age cohorts (14 and 6 respectively) prevent meaningful testing for statistical significance. At Poundbury Camp, a total of 11 infants were reported with active cribra orbitalia, whereas only one infant with active lesions was identified in the current study, from rural Bradley Hill. In the older children, the occurrence of active lesions was similar in the rural sites and Poundbury Camp at $24.8 \%$ and $21.0 \%$, respectively, compared to between 10 $15 \%$ in the urban site types (Table 7). The distribution of porotic hyperostosis is statistically significant $\left(X^{2}=19.73, \mathrm{p}<0.005\right.$, d.f. $\left.=3\right)$, with the highest rates observed at Poundbury Camp $(7.2 \%)$ and the rural sites $(6.2 \%)$, and low rates in the major urban $(1.4 \%)$ and minor urban sample $(2.8 \%)$ (Table 8$)$.

One probable and two possible cases of thalassaemia were identified at Poundbury Camp (Lewis 2012). Two further possible cases were identified in the major urban sites of Gloucester and one probable case at the Colchester colonia (Rohnbogner, 2016). All identified individuals are below the age of 24 months. Relative frequencies of possible cases of thalassaemia are at CPR $1.1 \%$ at Poundbury Camp $(n=3 / 276)$ and CPR $1.0 \%$ in the major urban sample $(n=3 / 314)$. [Table 8 here; Figure 6 here].

\section{Metabolic disease}

The prevalence of lesions indicative of vitamin D deficiency was reported to be $4.8 \%$ at Poundbury Camp, and recorded in $89.2 \%(n=33)$ of the children under 2.5 years (Lewis 2011) (Table 9). Particularly in the infants, there is a trend for higher rates observed at Poundbury Camp (CPR=18.8\%) compared to other Romano-British settlement types, although not significant $\left(X^{2}=6.49\right.$, d.f. $=3$ ). Vitamin D deficiency was reported similarly in 1.1-2.5 year olds from Durnovaria and major urban and rural sites (Fig. 7). In the combined rural cemeteries, scurvy was identified in $5.9 \%$ of the non-adults, compared to $4.8 \%$ at Poundbury Camp, although this difference was not significant. Interestingly, all rural children aged to 2.6 years and older with lesions indicative of scurvy stem from the Cannington cemetery in Somerset. Infantile scurvy was reported at similar rates in major urban and rural sites, as well as Poundbury Camp. In non-adults aged 1.1-2.5 years and older, there is a trend for higher rates of vitamin $\mathrm{C}$ deficiency on rural sites, closely followed by the rates of scurvy reported from Roman Dorchester (Table 9, Fig. 8). Across all sites, there were individuals 
that displayed lesions that may have arisen due to metabolic disease or nutritional shortages, however these were either distributed inconclusively, or the skeleton was not sufficiently preserved to make a conclusive diagnosis. [Table 9 here; Figure 7 and 8 here].

\section{DISCUSSION}

The study presents the first large-scale analysis of non-adult palaeopathological data from Roman Britain. By contextualising the findings from previously published Poundbury Camp, new insights can be gleaned into the lives and deaths of children across Britannia, rather than the Durnovaria civitas alone. Some of the key findings remind us that Poundbury Camp remains an exceptional site. Yet there are some similarities in lesion frequencies across the sites, particularly between Poundbury Camp and the rural cohort of this study that urge us to consider equally compromised living conditions across Roman Britain.

Significantly higher rates of infant burials on rural sites are apparent. High numbers of infant burials are frequently observed in Roman Britain and have sparked ongoing debates about infanticide (Gowland and Chamberlain, 2002; Gilmore and Halcrow, 2014), or exposure (Gowland et al., 2014; Millett and Gowland,2015). Low numbers of perinates at Poundbury Camp were observed, and when compared to the number of older infants, would suggest that exogenous factors were having little impact on the survival of babies born in to major urban settlements (Frenzen and Hogan, 1982; Scott and Duncan, 1999). This seems extremely unlikely given the potential hazards of overcrowding, poor hygiene and infections (Rawson, 2003:121; Roberts and Cox, 2003:123-30). It is feasible that differential burial rites reserved for the youngest impacted on the relative frequencies of infant burials between the site types. Indeed, intramural burial, exclusion from the formal cemetery, clustering in a dedicated area of the cemetery, or burial in a separate site altogether, have all been observed with infant burials in Roman Britain (Philpott, 1991; Scott, 1991; Pearce 1999; 2001; Esmonde Cleary, 2000; Wileman, 2005; Gowland et al., 2014). The observed patterns may be a reflection of cultural practices, rather than of mother and infant health, forcing us to approach infant mortality with caution.

At the other end of the age spectrum, the proportionately lower numbers of 6.6-10.5year olds living and dying in the countryside, may indicate the migration of these older children, either voluntarily of forced, to commence their working lives. While challenging to prove isotopically in regions where the urban and rural geology may be similar, we know that this type of migration occurred elsewhere in the Roman Empire (Prowse et al., 2007; Killgrove and Montgomery, 2016). 
Tuberculosis remains the quintessential urban disease of Roman Britain, although non-adult TB is no longer confined to Roman Dorchester and was also found in minor urban towns. The findings support previous research on the unsanitary and crowded urban environment (Roberts and Cox, 2005; Hall, 2005; Lewis 2011). However, non-adult TB that we can discern osteologically is merely the tip of the iceberg (Lewis, 2007). It is not until the post-primary/secondary phase of TB that skeletal changes occur, which requires either reinfection, or re-activation of the latent primary tuberculosis due to immune system suppression (Nelson and Wells, 2004; Roberts and Manchester, 2004:187). A compromised immune system aggravates the susceptibility to TB infection, and clinical studies attest a link between measles and whooping cough with increased TB risk (Nelson and Wells, 2004). Poor nutritional status also affects the severity and onset of the disease (Pfeiffer, 1984). Nonadults in major and minor urban environments not only experienced an increased risk of infection, but were also exposed to more prominent immunosuppressive factors than their rural peers. The trend for higher rates of pulmonary infection in major urban sites supports this argument, and is a witness to air pollution promoting respiratory ailments (Roberts and Buikstra, 2003; Roberts, 2007). In the absence of spinal involvement, the one possible case of rural TB is likely to be a respiratory infection. The adolescent from Cannington, Somerset, suggests that rural dwellings were poorly ventilated, and agrarian lifestyles would have forced close contact with animals and associated risks of infection.

The majority of individuals with new bone formation, particularly from Poundbury Camp and the urban sites, exhibited active new bone formation. Active lesions at the time of death may be a witness to ongoing, even chronic, health insults in these urban environments, perhaps stemming from generally poor health (Wood et al., 1992). However, the prevalence of sub-periosteal new bone formation as an indicator of non-specific stress contributes little to the debate due to the variety of causative agents such as generalised infection, neoplastic disease or trauma (Weston, 2012; DeWitte, 2014; Klaus, 2014). An additional limitation are the unique properties of non-adult bone. The non-adult periosteum is more prone to inflammation and tearing, and yet bone heals and remodels quicker than its adult equivalent, causing older lesions to be overlooked as a result of complete healing (Wenaden et al., 2005; Lewis 2007:133). The overall rate of skeletal pathologies in younger and older childhood may be a more viable indicator of general stress and health insults, which may combat some of these limitations. Skeletal pathology and age-at-death would suggest that growing up at Poundbury Camp proved most challenging in the early years, which is a stark reminder of the squalid nature of the settlement and maladaptive child rearing practices that may have been 
followed at the site (Roberts and Cox, 2003; Lewis, 2010). More children with skeletal pathologies survived past the age of five years old in the non-Poundbury sites. Increased resilience to stressors is commonly observed in those growing up in rural settings (Wells and Evans, 2003), and the evidence suggests that the more rustic environments of Roman Britain may have proved less taxing on young children. However in the first instance, we do have to consider that some of the younger non-adults may not have suffered from a disease for long enough to manifest skeletally. Nevertheless, the inverse relationship of pathology and age-atdeath observed at Poundbury Camp compared to the remainder of sites highlights the complex and unique nature of the burial assemblage at Roman Dorchester.

Lewis (2010) interpreted the prevalence of cribra orbitalia at Poundbury Camp as a witness of poor weaning foods, and unsanitary living conditions which prompted diarrhoeal diseases. The overall TPR of cribra orbitalia was significantly elevated at Poundbury Camp, a finding first reported by Stuart-Macadam (1991), forming the basis for Stuart-Macadam's recording scheme. However, we have to be cautious not to let these findings colour our understanding of the true extent of haematopoietic conditions in Roman Britain. To date, Poundbury Camp yielded the highest number of non-adults with probable thalassaemia, alongside one case from Roman Colchester (Rohnbogner, 2016), and two possible cases from Roman Gloucester where preservation prevents from making conclusive diagnoses. Although we now know that the disease is not exclusive to Roman Dorchester, high rates of cribra orbitalia at Poundbury Camp could be related to high levels of genetic anaemia, rather than lifestyle and environment (Lewis, 2012).

As suggested by Lewis (2010), women in Roman Dorchester who breastfed may have been under nutritional and environmental stress themselves (Katzenberg et al., 1996; Robit et al., 2013). Fasting may have been undertaken as an early Christian ritual, resulting in high rates of cribra orbitalia in young children, and particularly infants at Poundbury Camp (Lewis, 2010). Although the issue is complex, maternal mal- or undernutrition may be traced via haematopoietic and metabolic shortcomings in infants and weanlings, and may have influenced the differing relationship of skeletal pathology and survivorship at Poundbury Camp, compared to other site types (Fildes, 1986; Temkin, 1991; Garnsey, 1999; Rawson, 2003a; Gowland, 2015). The majority of individuals across all sites types with porotic hyperostosis (67.6\%), rickets (89.2\%) and scurvy (64.1\%) were younger than 2.5 years old. Formation of cranial porotic lesions in this age group may be related to maternal diets low in vitamins B6/B12 and iron, yielding insufficient levels of the micronutrients in breast milk (Kumar et al., 2008; Allen, 2012). The adverse effect of low maternal calcium intake is 
largely kept at bay by increased intestinal absorption of calcium during pregnancy, and depletion of skeletal calcium stores during breastfeeding (Kovacs, 2005). However, mothers that were extremely low in vitamin D could pass the deficiency on during pregnancy, and subsequently via breast milk with decreased vitamin D content (Wagner et al., 2008). In most cases, rickets as calcium deficiency is normally seen after two years in response to inadequate weaning and supplementary feeding (Thacher, 2006). Although rare, scurvy may be transferred from mother to child following severe malnourishment during pregnancy (Crandall, 2014; Robbins Schug and Blevins, 2016). The possibility of depleted ascorbic acid stores in breastfeeding mothers also have to be considered, potentially resulting in infants and young children receiving vitamin $\mathrm{C}$ deficient breast milk, which would have its most marked impact prior to supplementation (Salmenperä, 1984; Emmett and Rogers, 1997). Infantile scurvy was reported at comparable rates on all sites which indicates shortcomings in maternal health, weaning practices and associated foods across all settlement types. Additionally, high rates of scurvy in children aged 1.1-2.5 years old from rural sites and in the 'Christian' cohort at Poundbury Camp are apparent. The bulk of scorbutic children at Roman Dorchester stems from the 'non-pagan' or 'Christian' cohort, perhaps a result of 'Romanisation' and devotion to a higher power that demanded significant dietary and lifestyle changes particularly for women and children (Rutgers et al., 2009; Lewis 2010). An early Christian following in southwestern parts of later Roman Britain may have promoted an ascetic lifestyle for women (Cool, 2006), in turn affecting infants and weanlings.

Apart from physiological characteristics of the mothers, strategies during transitional feeding would have impacted on the wellbeing of weanlings (Fildes, 1986; Katzenberg et al., 1996; Robit et al., 2013). Generally, a lack of fresh fruits and vegetables in the weaning diet is not surprising, given Soranus' recommendation of cereal-based weaning foods which have been isotopically validated (Temkin, 1991; Powell et al., 2014). However, it was anticipated that rural children would have been weaned on vitamin $\mathrm{C}$ rich foods. Mothers in the countryside may have ceased breastfeeding earlier than around the isotopically ascribed 3year benchmark (Fuller et al., 2006; Nehlich et a., 2011; Redfern et al., 2012; Powell et al., 2014), leaving the child more susceptible to nutritional deficiencies including scurvy.

In modern populations the prevalence of rickets is highest in children aged 3-18 months, as vitamin D stores are diminished six months after birth and need to be replenished via sunlight (Pettifor and Daniels, 1997; Foote and Marriott, 2003). As recommended by Soranus, swaddling and wrapping infants in clothes once they sit up, may have been a universal practice across Roman Britain and excessively shielded children from the sun 
(Temkin, 1991:84-7,116). However, the clinical literature supports that swaddling has a marginal impact on vitamin D deficiency and promotes child wellbeing (Kutluk et al., 2002; van Sleuwen et al., 2007), and even fully clothed infants only need two hours of sunlight per week to maintain healthy bone structure (Pettifor and Daniels, 1997:665). In the crowded living quarters children may have been kept indoors during their younger years, due to lack of outdoor space and accidents on the busy roads and alleyways could be avoided. Parents and primary caregivers may have exhibited similar behaviours in rural settlements. Mothers working in the field would have covered their children and carried them in a sling, shielding away sunlight.

Some of the rachitic children may have been generally poorly (Snoddy et al., 2016). By keeping them indoors to recover and rest, vitamin D deficiency may have ensued, possibly exacerbated by low calcium levels in the diet, prolonged breastfeeding, and/or gastrointestinal maladies limiting calcium absorption, i.e. weanling's diarrhoea (Pettifor and Daniels, 1997; Buckley, 2000; Foote and Marriott, 2003). Rachitic infants were most frequently reported in Roman Dorchester and minor urban sites, yet 1.1-2.5 year olds exhibited similar frequencies among major urban, rural and both 'pagan' and 'Christian' Poundbury Camp children. The minor urban rate is elevated in infancy, and then drops to the lowest rate in 1.1-2.5 year olds. Either rachitic children in minor urban sites were less likely to live past infancy, or poverty and biased resource allocation impacted on children more severely after the first year of life. It appears that the distribution of vitamin D deficiency at Poundbury Camp is neither the norm, nor representative for Roman Britain, and that the disease itself may not be traced back to dress or cultural habits alone. However, cooccurrence of vitamin C/D deficiency causes rickets to be macroscopically masked by scorbutic lesions (Schattmann et al., 2016), and rachitic lesions are inhibited by starvation, i.e. severe protein-calorie deficiency (Adams and Berridge, 1969; Salimpour, 1975). It therefore has to be assumed that the actual rate of rickets was higher in Roman Britain due to limitations in recognising the disease osteologically, and the time elapsing between onset of deficiency and skeletal lesions.

A significantly higher prevalence of healed cribrotic lesions was reported at Poundbury Camp, however there was also a trend for higher rates of active cribra orbitalia in the rural children. The distribution of both cribra orbitalia and porotic hyperostosis is comparable at Poundbury Camp and the rural cohort, urging us to consider similarities in cultural practices and the living environment between Roman Dorchester and the countryside of southwestern Roman Britain. We may have to consider whether rural individuals were 
included in the Poundbury Camp cemetery, either by migration or living on rural sites in the hinterland or suburbium (Goodman, 2007:76-8; Laurence et al., 2011:288; Pearce, 2015). Results confirm elevated stress in the rural population as suggested by Griffin and Pitts (2012) and Redfern et al. (2015). We assume that a substantial portion of cribrotic lesions resulted from iron-deficiency anaemia and megaloblastic anaemia. Iron and vitamin B6/B12 are mainly obtained from the same food sources, i.e. red meat, pork, poultry, seafood, oatmeal and some vegetables (Baker et al. 2010; NHS 2015a). Previously published literature on dietary variability in Roman Britain attests that the consumption of plant foods, meat and fish was not uniform across social strata (King, 1984; 1999; 2001; Molleson, 1992; van der Veen, 2008; van der Veen et al., 2007; 2008; Cummings, 2009; Müldner, 2013). Although trace element analysis has revealed that those buried at Poundbury Camp ate a varied diet of meat, fish and plants, this may have been status dependent (Molleson, 1992).

Rural children may have experienced the same health insults as those at Poundbury Camp, possibly at a more pressing scale, causing them to develop even higher rates of orbital lesions in response to nutritional stress, infections, and high bacterial or parasitic pathogen loads (Stuart-Macadam, 1991; Holland and O'Brien, 1997; Wapler et al., 2004; Djuric et al., 2008; Walker et al., 2009; Oxenham and Cavill, 2010). If animal products were more difficult to access for lower status individuals as attested by zooarchaeological and isotopic studies (van der Veen et al., 2008; Cummings, 2009; Kilgrove and Tykot, 2012; Cheung et al., 2012; Müldner, 2013), the higher incidence of cribra orbitalia in rural children may indicate their lower status. Oatmeal itself was mainly reserved for animal fodder and only eaten occasionally (Cool, 2006:71; Britton and Huntley, 2011). Even among those consuming oatmeal, if the child suffered from a parasitic infection or diarrhoeal disease, the loss of nutrients would have presented a risk for iron and vitamin B6/B12 deficiencies when meat and fish were scarce (Holland and O'Brien, 1997; Facchini et al., 2004; Mahmud et al., 2013). Porotic lesions on the ectocranium were most common at Poundbury Camp and among rural non-adults, although prevalence is low overall. Redfern et al. (2015) observed porotic hyperostosis in $7.0 \%$ of individuals of all ages from rural sites in Roman Dorset, whereas no marrow hypertrophy in non-Poundbury Camp urban sites were observed. Migration into Roman Dorchester by rural individuals may have elevated the rates in the Poundbury Camp cemetery, or alternatively, rural dead from outlying villages and farmsteads may have been buried in the cemetery.

Contrary to what we would expect, endocranial lesions were lowest at Poundbury Camp and other major urban sites. More children in the rural cohort were affected, with 
significantly higher numbers in the minor urban cohort. Perhaps the distribution demonstrates that settlements with an agricultural focus yielded conditions likely to promote inflammation in children. Lewis (2016) observed higher rates of endocranial lesions in rural 10.0-13.9 year olds from early medieval England. Areas of rural poverty existed in the medieval period, and perhaps similar health insults were prompted by the social stratification of Romano-British society, causing greater levels of stress, inflammation and infection in rural children. Recent findings on health in the Roman suburbium demonstrate that life outside of the urban centres was taxing (Killgrove and Tykot, 2012), and Redfern and colleagues (2015) demonstrated that compromised health in rural settings was a reality across Roman Dorset. The greater numbers of inflammatory responses as measured by endocranial lesions may have also arisen due to vitamin deficiencies, trauma or rapid new bone growth during early childhood (Lewis, 2004; Zahareas, 2011). Vitamin C deficiency was prevalent among the rural cohort, and we would expect to see trauma in children as a result of agrarian lifestyles and close contact with livestock. Perhaps a number of those identified with endocranial lesions in the rural sample were suffering from the onset of metabolic disease, or cranial trauma which had not produced additional skeletal lesions at the time of death, or cannot be identified due to preservation.

A greater dispersal of vitamin $\mathrm{C}$ deficiency across older age groups was seen at Poundbury Camp and the rural sites. All of the rural children with possible scurvy aged 2.6 years and older originate from Cannington, Somerset, and all but one case of scurvy recorded in the rural children were active at the time of death (92.3\%), suggesting a chronic state of deficiency. It is important not to confuse the mal- or undernutrition seen with starvation (Mays, 2014). The NHS recommends a daily intake of 40mg of vitamin C per day for adults (NHS, 2015b). More is required for children and pregnant/lactating women (Brickley and Ives, 2008:48; National Institutes of Health, 2011), yet clinical symptoms only start to develop once less than 10mg are available per day (Hodges et al., 1971; Stark, 2014). The minimum intake is covered by small amounts of fruits and vegetables, such as a cup of leek or pear (USDA National Nutrient Database, 2013). Pimentel (2003) stated that clinical symptoms will improve within two weeks after daily ingestion of $200 \mathrm{mg}$ of ascorbic acid, although skeletal lesions may take years to remodel entirely (Parfitt, 2002; 2004). Rural children did not experience starvation but rather a restricted diet, as some low levels of ascorbic acid were present to initiate bony changes (Crandall et al., 2012; Stark, 2014).

It may be suggested that the underlying social and economic causes resulting in infantile scurvy at Poundbury Camp and the rural sites were not the same. To date, the high levels of scurvy seen at Poundbury Camp are interpreted as the result of, perhaps even 
voluntary, dietary restrictions that accompanied a new belief system (Cool, 2006). Rural infants may have developed scurvy due to withholding of resources, where access to foods was regulated by a market economy (Pitts, 2008). Given the context, the health implications of biased food allocation and resource distribution between urban and rural communities need to be considered (Whittaker and Garnsey, 1997:284; Redfern et al., 2015), as stress perpetuated by political and economic factors (Klaus, 2012; Crandall, 2014). If the population in the countryside was mainly concerned with having to provide for the urban population and army, a substantial portion of produce would have been reserved for trade and taxes (Scheidel and von Reden, 2002). Particularly at Cannington, Somerset, scurvy in the children aged 2.6 years and older may be linked with possible site characteristics of quarrying and large-scale organised exploitation of the land for farming (Rahtz, 2000:393,423), taking its toll on the mothers and children and potentially generating an influx of low-grade workers (McCarthy, 2013:102).

Peasant families would have lived in oppressive conditions compromising their diet, mental and physical wellbeing, a by-product of manorial or otherwise exploitative landownership and tenancy (de la Bédoyère, 1993:86; Jones 1996:208). Land would have been distributed to peasant farmers in late Roman Britain, based on the renewal of an annual lease. By the 4th century however, tenants became legally tied to the estate and land tenancy became hereditary. This made the process of taxation easier to oversee whilst also relieving the landowner of having to provide food and accommodation to the workers (de la Bédoyère, 1993:86). Bonded workers would therefore not only have been customary to late RomanoBritish villae, but tenancy affected the farmers in villages outside of villa estates (de la Bédoyère, 1993:74-5; Jones 1996:208-15). The malnutrition observed in rural RomanoBritish children may be a result of oppressive landownership, affecting food security and distribution in the countryside (Crandall, 2014). Social change and status differences inherently define the foods people have access to, and differences may have been pronounced in Roman Britain, affecting those at the bottom of the social ladder most profoundly (Armelagos et al., 2014). In theory, the state of deprivation on rural sites would also impact on the adults, particularly the females who will perpetuate a cycle of deprivation and depressed health status over several generations (Gowland, 2015). Although there is increasing awareness of marked ill-health beyond the city walls, both at Rome (Cucina et al., 2006) and in Roman Britain (Redfern et al., 2015), more research incorporating adult and non-adult osteological and isotopic data is desired to evaluate the full extent of health implications rural inhabitants may have experienced under Roman rule. 


\section{CONCLUSION}

First and foremost, Poundbury Camp was the archetypal site that presented palaeopathologists with detailed data on child health, allowing us to question previous assumptions about urban living in the Roman period. The site's contribution to current knowledge on childhood in Roman Britain, particularly in major urban settlements, is invaluable. Yet, Romano-British bioarchaeology is faced with a lack of comparative data to contextualise the high levels of ill-health witnessed in the Poundbury Camp non-adults. The problem is particularly pronounced with a view to rural settlements, as children of the countryside remain notoriously understudied. Naturally, the study relies on the children that died and were buried at major urban, minor urban and rural sites. As with any study that explores morbidity and mortality in the past, it is influenced by burial practices, preservation, excavation and the movement of people (Wood et al., 1992; 2002). Despite its limitations it presents the most comprehensive overview of non-adult health in Roman Britain to date.

The research discussed here provides new perspectives and increases our breadth of understanding of rural lifeways, adding to the debate on everyday life in the towns and countryside of Roman Britain. The results demonstrate that ill-health in Romano-British children was shaped by settlement type, and further highlight the somewhat unusual nature of Poundbury Camp as a major urban cemetery, particularly with view to the association of skeletal pathology and age-at-death. An overarching observation is that health was generally poor across Roman Britain, with children of all site types affected by metabolic disease, haematopoietic disturbances and infection. Some similarity is apparent between Roman Dorchester and other major urban sites, particularly in the diseases that relate to living environment, such as tuberculosis and vitamin D deficiency. Unexpectedly, the children from major urban cemeteries did not consistently show the highest lesion frequencies, and childhood pulmonary infection is no longer an exclusively urban disease. Overall, vitamin C deficiency and cribra orbitalia affected rural children at higher rates. Upon considering socioeconomic and political factors that would have shaped land management and tenancy in southern and western England, we can glean how deficiency diseases would have been sustained by these children. Rural poverty affected those growing up in the countryside to a similar extent as non-local cultural habits may have done at Poundbury Camp, brandishing the site as unique among its other major urban counterparts. 


\section{ACKNOWLEDGEMENTS}

This research was funded by an AHRC Studentship. We thank the curators who provided access to the skeletal collections for this project: Robert Kruszynski, Natural History Museum London; Keith Fitzpatrick-Matthews, North Hertfordshire District Council Museums Service; Dr Simon Mays, English Heritage; Christiane Jeuckens, Oxfordshire Museums Service; Dr Jo Buckberry, Biological Anthropology Research Centre; Steve Minnitt, Somerset Heritage Centre; David Allen, Hampshire Arts and Museums Service; Sarah Wilson, Vivacity Peterborough Museum and Art Gallery; Helen Rees, Winchester Museum Service; Lorraine Cornwell, Rutland County Museum; Alison Brooks and Heather Dawson, Corinium Museum; Dr Paul Sealey and Jessica Dowdell, Colchester and Ipswich Museums and Timothy Vickers, Luton Culture. Special thanks to Jessica Dowdell at Colchester and Ipswich Museums and Sarah Wilson at Vivacity Peterborough Museum and Art Gallery for authorising publication of the photographs.

\section{LITERATURE CITED}

Adams P, Berridge FR 1969. Effects of kwashiorkor on cortical and trabecular bone. Arch Dis Child 44:705-709.

Allen LH. 2012. B vitamins in breast milk: relative importance of maternal status and intake, and effects on infant status and function. Adv Nutr 3:362-369.

Armelagos GJ, Sirak K, Werkema T, Turner B L. 2014. Analysis of nutritional disease in prehistory: the search for scurvy in Antiquity and today. Int J Paleopath 5:9-17.

Baker RD, Greer FR, Committee on Nutrition. 2010. Clinical report - diagnosis of iron deficiency and iron-deficiency anemia in infants and young children (0-3 years of age). Pediatrics 126:1-11.

Breeze DJ, editor. 2014. The impact of Rome on the British countryside. A conference organised by the Royal Archaeological Institute, Chester, 11-13 October 2013. London: Royal Archaeological Institute Supplementary Publication.

Brickley M, Ives R. 2006. Skeletal manifestations of infantile scurvy. Am J of Phys Anthropol 129:163-172. 
Brickley M, Ives R. 2008. The bioarchaeology of metabolic bone disease. London: Elsevier.

Britton K, Huntley J. 2011. New evidence for the consumption of barley at Romano-British military and civilian sites, from the analysis of cereal bran fragments in faecal material.

Vegetation History and Archaeobotany 20:41-52.

Buckley HR. 2000. Subadult health and disease in prehistoric Tonga, Polynesia. Am J Phys Anthropol 113:481-505.

Burleigh GR, Fitzpatrick-Matthews KJ. 2010. Excavations at Baldock, Hertfordshire, 19781994 - Volume 1 - An Iron Age and Romano-British cemetery at Wallington Road. Hitchin: North Hertfordshire District Council Museums Service and North Hertfordshire Archaeological Society.

Burnham BC. 1993. The small towns of Roman Britain - the last 50 years. In: Greep SJ, editor. Roman towns: The Wheeler Inheritance. York: CBA Research Report 93. p 99-110.

Burnham BC. 1995. Small towns: the British perspective. In: Brown AE, editor. Roman small towns in eastern England and beyond. Oxford: Oxbow Monograph 52. p 7-18.

Burnham BC, Wacher J. 1990. The small towns of Roman Britain. London: Batsford.

Burnham BC, Collis J, Dobinson C, Haselgrove C, Jones M. 2001. Themes for urban research, c 100 BC to AD 200. In: James S, Millett M, editors. Britons and Romans: Advancing an archaeological agenda. York: CBA Research Report 125. p 67-76.

Chambers RA. 1987. The late and sub-Roman cemetery at Queenford Farm, Dorchester-onThames, Oxon. Oxoniensia 52: 35-70.

Cheung C, Schroeder H, Hedges REM. 2012. Diet, social differentiation and social change in Roman Britain: new isotopic evidence from Gloucestershire. Archaeol Anthropol Sci 4:6173.

Clough S, Boyle A. 2010. Inhumations and disarticulated human bone. In: Booth P, Simmonds A, Boyle A, Clough S, Cool HEM, Poore D. The late Roman cemetery at Lankhills, Winchester - excavations 2000-2005. Oxford: Oxford Archaeology. p 339-399.

Collis JR. 1968. Excavations at Owslebury, Hampshire: an interim report. Antiqu J 48: 18-31. Collis J. 1977. Owslebury (Hants) and the problem of burials on rural settlements. In: Reece $\mathrm{R}$, editor. Burial in the Roman world. York: CBA Research Report 22. p 26-34 
Cool HEM. 2006. Eating and drinking in Roman Britain. Cambridge: Cambridge University Press.

Cox M. 1989. The human bones from Ancaster. London: Unpublished Ancient Monuments Laboratory Report 93/89.

Crandall JJ. 2014. Scurvy in the Greater American Southwest: modelling micronutrition and biosocial processes in contexts of resource stress. Int J Paleopath 5:46-54.

Crandall JJ, Klaus HD. 2014. Advancements, challenges and prospects in the paleopathology of scurvy: current perspectives on vitamin $\mathrm{C}$ deficiency in human skeletal remains. Int $\mathrm{J}$ Paleopath 5:1-8.

Crandall JJ, Martin DL, Thompson JL. 2012. Inferring severity from lesion patterning in cases of infantile scurvy. In: Scientific Program of the Paleopathology Association 39th Annual Meeting (North America), April 10-11, Portland, OR, 12.

Crummy N, Crossan C. 1993. Excavations at Butt Road cemetery, 1976-9, 1986 and 1989. In: Crummy N, Crummy P, Crossan C. Colchester Archaeological Report 9: Excavations of Roman and later cemeteries, churches and monastic sites in Colchester, 1971-88. Colchester: Colchester Archaeological Trust. p 4-163.

Cucina A, Vargin R, Mancinelli D, Ricci R, Santandrea E, Catalano P, Coppa A. 2006. The necropolis of Vallerano (Rome, 2nd-3rd century AD): an anthropological perspective on the ancient Romans in the Suburbium. Int J Osteoarchaeol 16:104-117.

Cummings C. 2009. Meat consumption in Roman Britain: the evidence from stable isotopes. In: Driessen M, Heeren S, Hendriks J, Kemmers F, Visser R, editors. TRAC 2008: Proceedings of the eighteenth annual Theoretical Roman Archaeology Conference. Oxford: Oxbow Books. p 73-83.

de la Bédoyère G. 1993. English Heritage Book of Roman villas and the countryside. London: BT Batsford/English Heritage.

DeWitte SN. 2014. Health in post-Black Death London (1350-1538): age patterns of periosteal new bone formation in a post-epidemic population. Am J Phys Anthropol 155:260267.

Dix B. 1983. Ashton Roman town. SMidlA 13: 18-20. 
Djuric M, Milovanovic P, Janovic A, Draskovic M, Djukic K, Milenkovic P. 2008. Porotic lesions in immature skeletons from Stara Torina, Late Medieval Serbia. Int J Osteoarchaeol 18:458-475.

Durham B, Rowley T. 1972. A cemetery site at Queensford Mill, Dorchester. Oxoniensia 37: $32-38$.

Emmett PM, Rogers IS. 1997. Properties of human milk and their relationship with maternal nutrition. Early Hum Develop 49:S7-S28.

Esmonde Cleary S. 2000. Putting the dead in their place: burial location in Roman Britain. In: Pearce J, Millett M and Struck M, editors. Burial, society and context in the Roman world. Oxford: Oxbow. p 127-1429.

Esmonde Cleary S. 2004. Britain in the fourth century. In: Malcolm T, editor. A companion to Roman Britain. Oxford: Blackwell Publishing. p 409-427.

Facchini F, Rastelli E, Brsili P. 2004. Cribra orbitalia and cribra cranii in Roman skeletal remains from the Ravenna area and Rimini (I-IV century AD). Int J Osteoarchaeol 14:126136.

Faith R. 1997. The English peasantry and the growth of lordship. London: Leicester University Press.

Farwell DE, Molleson TI, editors. 1993. Poundbury Volume 2 - The Cemeteries. Dorchester: Dorset Natural History and Archaeology Society, Monograph 11.

Fildes V. 1986. Breasts, bottles and babies - a history of infant feeding. Edinburgh: Edinburgh University Press.

Foote K, Marriott L. 2003. Weaning of infants. Arch Dis Child 88:488-492.

Frend WHC. 1992. Pagans, Christians, and the 'Barbarian Conspiracy' of AD 367 in Roman Britain. Britannia 23:121-131.

Frenzen PD, Hogan DP. 1982. The impact of class, education, and health care on infant mortality in a developing society: the case of rural Thailand. Demography 19:391-408.

Fuller BT, Molleson TI, Harris DA, Gilmour LT, Hedges REM. 2006. Isotopic evidence for breastfeeding and possible adult dietary differences from Late/Sub-Roman Britain. Am J Phys Anthropol 129:45-54. 
Garnsey P. 1999. Food and society in classical antiquity. Cambridge: Cambridge University Press.

Gerrard J. 2011. New radiocarbon dates from the cemetery at Bradley Hill, Somerton. Proc Somerset Archaeol Nat Hist Soc 154:189-193.

Gilmore H, Halcrow SE. 2014. Interpretations of infanticide in the past. In: Thompson JL, Alfonso-Durruty MP, Crandall JJ, editors. Tracing childhood: bioarchaeological investigations of early lives in antiquity. Gainesville: University Press of Florida. p 123-138.

Goodman PJ. 2007. The Roman city and its periphery - from Rome to Gaul. London: Routledge.

Goodman AH, Rose JC. 1990. Assessment of systemic physiological perturbations from dental enamel hypoplasias and associated histological structures. Am J Phys Anthropol 33S11:59-110.

Gowland RL. 2015. Entangled lives: implications of the developmental origins of health and disease hypothesis for bioarchaeology and the life course. Am J Phys Anthropol 158:530540.

Gowland RL, Chamberlain AT. 2002. A Bayesian approach to ageing perinatal skeletal material from archaeological sites: implications for the evidence for infanticide in Roman Britain. J Archaeol Sci 29:677-685.

Gowland R, Redfern R. 2010. Childhood health in the Roman world: perspectives from the centre and margin of the Empire. Child Past 3:15-42.

Gowland R, Chamberlain A, Redfern RC. 2014. On the brink of being: re-evaluating infanticide and infant burial in Roman Britain. J Roman Archaeol 96:69-88.

Griffin R, Pitts M. 2011. Inequality at late Roman Baldock, UK - the impact of social factors on health and diet. J Anthropol Res 67:533-556.

Halcrow SE, Tayles N. 2008. The bioarchaeological investigation of childhood and social age: problems and prospects. J Archaeol Method Th 15:190-215.

Halcrow SE, Tayles N. 2011. The bioarchaeological investigation of children and childhood. In: Agarwal S, Glencross BA, editors. Social bioarchaeology. Malden: Wiley-Blackwell. p 333-360. 
Hall J. 2005. The shop-keepers and craft-workers of Roman London. In: MacMahon A, Price J, editors. Roman working lives and urban living. Oxford: Oxbow Books. p 125-144.

Heighway CM. 1980. Roman cemeteries in Gloucester District. Trans BGAS 98: 57-72.

Hingley R. 1989. Rural settlement in Roman Britain. London: Seaby.

Hodges RE, Hood J, Canham JE, Sauberlich HE, Baker EM. 1971. Clinical manifestations of ascorbic acid deficiency in man. Am J Clin Nutr 24:432-443.

Holland TD, O’Brien MJ. 1997. Parasites, porotic hyperostosis, and the implications of changing perspectives. Am Antiq 62:183-193.

Hurst HR. 1985. Kingsholm - Excavations at Kingsholm Close and Other Sites with a Discussion of the Archaeology of the Area. Stroud: Gloucester Archaeological Publications.

Hurst HR. 1986. Gloucester - the Roman and later defences. Stroud: Gloucester Archaeological Publications.

Jones M. 1982. Crop production in Roman Britain. In: Miles D, editor. The Romano-British countryside - studies in rural settlement and economy. Oxford: BAR British Series 103. p 97108.

Jones ME. 1996. The end of Roman Britain. London: Cornell University Press.

Katzenberg MA, Herring DA, Saunders SR. 1996. Weaning and infant mortality: evaluating the skeletal evidence. Yearb Phys Anthropol 39:177-199.

Killgrove K, Tykot RH. 2013. Food for Rome: a stable isotope investigation of diet in the Imperial period $\left(1^{\text {st }}-3^{\text {rd }}\right.$ centuries AD). J Anthropol Archaeol 32:28-38.

Killgrove K, Montgomery J. 2016. All roads lead to Rome: exploring human migration to the eternal city through biochemistry of skeletons from two Imperial-era cemeteries $\left(1^{\text {st }}-3^{\text {rd }} \mathrm{c}\right.$ AD). PLoS One 11. DOI: 10.1371/journal.pone.0147585.

King AC. 1984. Animal bones and the dietary identity of military and civilian groups in Roman Britain, Germany and Gaul. In: Blagg T, King A, editors. Military and civilian in Roman Britain: Cultural relationships in a frontier province. Oxford: BAR British Series 136. p 187-217.

King AC. 1999. Diet in the Roman world: a regional inter-site comparison of the mammal bones. J Roman Archaeol 12:168-202. 
King A. 2001. The Romanization of diet in the Western Empire: Comparative archaeological studies. In: Keay S, Terrenato N, editors. Italy and the West - comparative issues in Romanization. Oxford: Oxbow Books. 210-226.

Klaus HD. 2014. Frontiers in the bioarchaeology of stress and disease: cross-disciplinary perspectives from pathophysiology, human biology, and epidemiology. Am J Phys Anthropol 155:294-308.

Klaus HD, Tam ME. 2009. Contact in the Andes: bioarchaeology of systemic stress in colonial Mórrope, Peru. Am J Phys Anthropol 139:204-221.

Kovacs CS. 2005. Calcium and bone metabolism during pregnancy and lactation. J Mammary Gland Biol Neoplasia 10:105-118.

Kumar A, Rai AK, Basu S, Dash D, Singh JS. 2008. Cord blood and breast milk iron status in maternal anemia. Pediatr 121:673-677.

Kutluk G, FeyzullahC, Muzaffer B. 2002. Comparisons of oral calcium, high dose vitamin D and a combination of these in the treatment of nutritional rickets in children. $\mathrm{J}$ Trop Pediatr 48:351-353.

Lagia A, Eliopoulus C, Manolis S. 2007. Thalassaemia: macroscopic and radiological study of a case. Int J Osteoarchaeol 17:269-285.

Laurence R, Esmonde Cleary S, Sears G. 2011. The city in the Roman West c.250 BC c.AD 250. Cambridge: Cambridge University Press.

Lawson J, Ablow R, Pearson H. 1981. The ribs in thalassemia I: the relationship to therapy. Pediatr Radiol 140:663-672.

Lawson J, Ablow R, Pearson H. 1981. The ribs in thalassemia II: the pathogenesis of the changes. Pediatr Radiol 140:673-679.

Leech R. 1982. Excavations at Catsgore 1970-1973 - a Romano-British village. Taunton: Western Archaeological Trust Excavation Monograph 2.

Leech R, Besly EM, Everton RF. 1981. The excavation of a Romano-British farmstead and cemetery on Bradley Hill, Somerton, Somerset. Britannia 12: 177-252. 
Lewis M. 2002. Urbanisation and child health in medieval and post-medieval England - an assessment of the morbidity and mortality of non-adult skeletons from the cemeteries of two urban and two rural sites in England (AD850-1859). Oxford: BAR British Series 339.

Lewis ME. 2004. Endocranial lesions in non-adult skeletons: understanding their aetiology. Int J Osteoarchaeol 14:82-97.

Lewis ME. 2007. The bioarchaeology of children - perspectives from biological and forensic anthropology. Cambridge: Cambridge University Press.

Lewis ME. 2010. Life and death in a civitas capital: metabolic disease and trauma in the children from late Roman Dorchester, Dorset. Am J Phys Anthropol 142:405-416.

Lewis ME. 2011. Tuberculosis in the non-adults from Romano-British Poundbury Camp, Dorset, England. Int J Paleopath 1:12-23.

Lewis ME. 2012. Thalassaemia: its diagnosis and interpretation in past skeletal populations. Int J Osteoarchaeol 22:685-693.

Lewis ME. 2016. Work and the adolescent in Medieval England (AD 900-1550): the osteological evidence. Mediev Archaeol 60.

Lewis M, Roberts C. 1997. Growing pains: the interpretation of stress indicators. Int J Osteoarchaeol 7:581-586.

Mahmud MA, Spigt M, Bezabih AM, Pavon IL, Dinant G, Velasco RB. 2013. Risk factors for intestinal parasitosis, anaemia, and malnutrition among school children in Ethiopia. Pathog Glob Health 107:58-65.

Matthews CL. 1981. A Romano-British inhumation cemetery at Dunstable. Beds Archaeol J 15.

Mattingly DJ. 1997. Beyond belief? Drawing a line beneath the consumer city. In: Parkins HM, editor. Roman urbanism - beyond the consumer city. London: Routledge. p 210-218. Mattingly D. 2006. An imperial possession - Britain in the Roman Empire. London: Penguin Group.

Mays S. 2014. The paleopathology of scurvy in Europe. Int J Paleopath 5:55-62.

Mays S, Brickley M, Ives R. 2006. Skeletal manifestations of rickets in infants and young children in a historic population from England. Am J Phys Anthropol 129:362-374. 
McCarthy M. 2013. The Romano-British peasant - towards a study of people, landscapes and work during the Roman occupation of Britain. Oxford: Oxbow Books.

McConnell D, Grassam A, Mustchin A. 2012. Land adjacent to Great Casterton Primary School, Pickworth Road, Great Casterton, Rutland. Bury St. Edmunds: Archaeological Solutions Limited Unpublished Report.

McIlvaine BK. 2013. Implications of reappraising the iron-deficiency anemia hypothesis. Int J Osteoarchaeol 25:997-1000.

Mensforth RP, Lovejoy CO, Lallo JW and Armelagos GJ. 1978. The role of constitutional factors, diet, and infectious disease in the etiology of porotic hyperostosis and periosteal reactions in prehistoric infants and children. Med Anthropol 2:1-59.

Millett M. 1990. The Romanization of Britain - an essay in archaeological interpretation. Cambridge: Cambridge University Press.

Millett M. 1995. English Heritage Book of Roman Britain. London: Sterling Publishing.

Millett M. 1999. Coloniae and Romano-British studies. J Roman Archaeol 36:191-196.

Millett M. 2001. Approaches to urban societies. In: James S, Millett M, editors. Britons and Romans: Advancing an archaeological agenda. York: CBA Research Report 125. p 60-66.

Millett M, Gowland R. 2015. Infant and child burial rites in Roman Britain: a study from east Yorkshire. Britannia 46:171-189.

Molleson T. 1989. Social implications of mortality patterns of juveniles from Poundbury Camp, Romano-British cemetery. Anthropol Anz 47:27-38.

Molleson T. 1992. The anthropological evidence for change through Romanisation of the Poundbury population. Anthropol Anz 50:179-189.

Molleson TI. 1993. Part 2 The human remains. In: Farwell DE, Molleson TI, editors. Poundbury volume 2 - the cemeteries. Dorchester: Dorset Natural History and Archaeology Society, Monograph 11. p 142-214.

Molleson T, Cox M. 1988. A neonate with cut bones from Poundbury Camp. Bull Soc R Belge Anthropol Prehist 99:53-59.

Morley N. 2005. The salubriousness of the Roman city. Unpublished paper. University of Bristol, UK. 
Moorrees CFA, Fanning EA, Hunt EE. 1963a. Age variation of formation stages for ten permanent teeth. J Dent Res 42:1490-1502.

Moorrees CFA, Fanning EA, Hunt EE. 1963b. Formation and resorption of three deciduous teeth in children. Am J Phys Anthropol 21:205-213.

Mullin D. 2006. The archaeological landscape of Frampton-on-Severn, Gloucestershire: updated project design. Stroud: Gloucester Archaeology Service

Müldner G. 2013. Stable isotopes and diet: their contribution to Romano-British research Antiquity 87:137-149.

National Institutes of Health. 2011. Vitamin C fact sheet for consumers. Bethesda, Office of Dietary Supplements. Available from: http://ods.od.nih.gov [accessed 07/05/2015]

Nehlich O, Fuller BT, Jay M, Mora A, Nicholson RA, Smith CI, Richards MP. 2011. Application of sulphur isotope ratios to examine weaning patterns and freshwater fish consumption in Roman Oxfordshire, UK. Geochi Cosmochim Acta 75:4963-4977.

Nelson LJ, Wells CD. 2004. Global epidemiology of childhood tuberculosis. Int J Tuberc Lung Dis 8:636-647.

Newman SL, Gowland RL. 2016. Dedicated followers of fashion? Bioarchaeological perspectives on socio-economic status, inequality, and health in urban children from the Industrial Revolution $\left(18^{\text {th }}-19^{\text {th }} \mathrm{C}\right)$, England. Int J Osteoarchaeol DOI: 10.1002/oa.2531.

NHS. 2015a. NHS Choices: vitamins and minerals - B vitamins and folic acid. London: Department of Health. Available from: http://www.nhs.uk [accessed 20/04/2015].

NHS. 2015b. NHS Choices: vitamins and minerals - Vitamin C. London: Department of health. Available from http://www.nhs.uk [accessed 07/05/2015].

Ortner DJ. 2003. Identification of pathological conditions in human skeletal remains (2nd edition). San Diego: Academic Press.

Ortner DJ, Ericksen MF. 1997. Bone changes in the human skull probably resulting from scurvy in infancy and childhood. Int J Osteoarchaeol 7:212-220.

Ortner DJ, Mays S. 1998. Dry-bone manifestations of rickets in infancy and early childhood. Int J Osteoarchaeol 8:45-55. 
Ortner D, Kimmerle E, Diez M. 1999. Probable evidence of scurvy in subadults from archaeological sites in Peru. Am J Phys Anthropol 108:321-331.

Ortner D, Butler W, Cafarella J, Milligan L. 2001. Evidence of probable scurvy in subadults from archaeological sites in North America. Am J Phys Anthropol 114:343-351.

Ottaway P. 2009. Roman York. Stroud: The History Press.

Ottaway PJ, Qualmann KE, Rees H, Scobie GD. 2012. The Roman cemeteries and suburbs of Winchester - excavations 1971-86. Winchester: Winchester Museums and English Heritage.

Oxenham MF, Cavill I. 2010. Porotic hyperostosis and cribra orbitalia: the erythropoietic response to iron-deficiency anaemia. Anthropol Sci 118:199-200.

Parfitt AM. 2002. Misconceptions (2): turnover is always higher in cancellous than cortical bone. Bone 30:807-809.

Parfitt AM. 2004. What is the normal rate of bone remodelling? Bone 35:1-3.

Pearce J. 1999. The dispersed dead: preliminary observations on burial and settlement space in rural Roman Britain. In: Baker P, Forcey C, Jundi S and Witcher R, editors. TRAC 98: proceedings of the eighth annual Theoretical Roman Archaeology Conference, Leicester 1998. Oxford: Oxbow. p 151-162.

Pearce J. 2001. Infants, cemeteries and communities in the Roman provinces. In: Davies D, Gardner A and Lockyear K, editors. TRAC 2000: proceedings of the tenth annual Theoretical Roman Archaeology Conference, London 2000. Oxford: Oxbow. p 125-142.

Pearce J. 2008. Burial evidence from Roman Britain - the un-numbered dead. In: Ecole Francaise de Rome. Pour une archaéologie du rite. Nouvelles perspectives de l'archaéologie funéraire, études réunies par John Scheid. Paris: Collection de L'Ecole Francaise de Rome. p $29-42$.

Pearce J. 2015. Urban exits: commercial archaeology and the study of death rituals and the dead in the towns of Roman Britain. In: Fulford M, Holbrook N, editors. The towns of Roman Britain - the contribution of commercial archaeology since 1990. Society for the Promotion of Roman Studies: Britannia, Monograph 27. p 138-166. 
Perry MA. 2005. Redefining childhood through bioarchaeology: toward an archaeological and biological understanding of children in antiquity. Archaeol Pap Am Anthropol Assoc 15:89-111.

Pettifor JM. 2014. Calcium and vitamin D metabolism in children in developing countries. Ann Nutr Metab 64:15-22.

Pettifor J, Daniels E. 1997. Vitamin D deficiency and nutritional rickets in children. In: Feldman D, Glorieux F, Pike J, editors. Vitamin D. New York: Academic Press. p 663-678.

Pfeiffer S. 1984. Paleopathology in an Iroquoian ossuary, with special reference to tuberculosis. Am J Phys Anthropol 65:181-189.

Pfeiffer S. 1991. Rib lesions and New World tuberculosis. Int J Osteoarchaeol 1:191-198.

Philpott R. 1991. Burial practice in Roman Britain - a survey of grave treatment and furnishing AD 43-410. Oxford: BAR British Series 219.

Pimentel L. 2003. Scurvy: historical review and current diagnostic approach. Am J Emerg Med 21:328-332.

Pitts M. 2008. Globalizing the local in Roman Britain: an anthropological approach to social change. J Anthropol Archaeol 27:493-506.

Pitts M, Griffin R. 2012. Exploring health and social well-being in late Roman Britain: an intercemetery approach. Am J Archaeol 116:253-276.

Powell LA, Redfern RC, Millard AR, Gröcke DR. 2014. Infant feeding practices in Roman London: evidence from isotopic analyses. J Roman Archaeol 96:89-110.

Prowse TL, Saunders SR, Schwarcz HP, Garnsey P, Macchiarelli R, Bondioli L. 2008. Isotopic and dental evidence for infant and young child feeding practices in an Imperial Roman skeletal sample. Am J Phys Anthropol 137:294-308.

Rahtz P, Hirst S, Wright SM. 2000. Cannington cemetery - excavations 1962-3 of prehistoric, Roman, post-Roman, and later features at Cannington Park Quarry, near Bridgwater, Somerset. London: Britannia, Monograph Series 17.

Rawson B. 2003. Children and childhood in Roman Italy. Oxford: Oxford University Press. 
Redfern R. 2007. The influence of culture upon childhood: an osteological study of Iron Age and Romano-British Dorset, England. In: Harlow M, Laurence R, editors. Age and ageing in the Roman Empire. Journal of Roman Archaeology Supplementary Series 65. p 171-190.

Redfern R. 2008. A bioarchaeological investigation of cultural change in Dorset, England (mid-to-late fourth century B.C. to the end of the fourth century A.D.). Britannia 39:161-191.

Redfern R, Roberts CA. 2005. Health in Romano-British urban communities: reflections from the cemeteries. In: Smith DN, Brickley MB, Smith W, editors. Fertile ground: Papers in honour of Susan Limbey. Oxford: Oxbow Books. p 115-129.

Redfern RC, Millard AR, Hamlin C. 2012. A regional investigation of subadult dietary patterns and health in late Iron Age and Roman Dorset. J Archaeol Sci 39:1249-1259.

Redfern RC, DeWitte SN, Pearce J, Hamlin C, Dinwiddy KE. 2015. Urban-rural differences in Roman Dorset, England: a bioarchaeological perspective on Roman settlements. Am J Phys Anthropol 157:107-120.

Resnick D, Kransdorf MJ. 2005. Bone and joint imaging (3rd edition). Philadelphia: Elsevier Saunders.

Robbins Schug G, Blevins KE. 2016. The center cannot hold: a bioarchaeological perspective on environmental crisis in the second millennium BCE, South Asia. In: Robbins Schug G, Walimbe SR, editors. A companion to South Asia in the past. Chichester: Wiley Blackwell. p $255-273$

Roberts CA. 2007. A bioarchaeological study of maxillary sinusitis. Am J Phys Anthropol 133: 792-807.

Roberts CA, Buikstra JE. 2003. The bioarchaeology of tuberculosis - a global view on a reemerging disease. Gainesville: University Press of Florida.

Roberts C, Cox M. 2003. Health and disease in Britain - from prehistory to the present day. Stroud: Sutton Publishing.

Roberts C, Manchester K. 2010. The archaeology of disease (3rd edition). Stroud: History Press. 
Robit B, Aranda N, Giralt M, Romen M, Balaguer A, Arija V. 2013. Effect of different doses of iron supplementation during pregnancy on maternal and infant health. Ann Hematol 92:221-229.

Rogers A. 2011. Late Roman towns in Britain: rethinking change and decline. Cambridge: Cambridge University Press.

Rohnbogner A. 2016. Differential diagnosis of a probable case of non-adult thalassaemia from $4^{\text {th }}$ century Ad Romano-British Colchester, UK. Int J Paleopath DOI:10.1016/j.ijpp.2016.08.002.

Rutgers LV, van Strydonck M, Boudin M, van der Linde C. 2009. Stable isotope data from the early Christian catacombs of ancient Rome: new insights into the dietary habits of Rome's early Christians. J Archaeol Sci 36:1127-1134.

Salimpour R, 1975. Rickets in Tehran - study of 200 cases. Arch Dis Child 50:63-67.

Salmenperä L. 1984. Vitamin C nutrition during prolonged lactation: optimal in infants while marginal in some mothers. Am J Clin Nutr 40:1050-1056.

Santos AL, Roberts CA. 2001. A picture of tuberculosis in young Portuguese people in the early 20th century: a multidisciplinary study of the skeletal and historical evidence. Am J Phys Anthropol 115:38-49.

Schattmann A, Bertrand B, Vatteoni S, Brickley M. 2016. Approaches to co-occurrence: scurvy and rickets in infants and young children of $16-18^{\text {th }}$ century Douai, France. Int $\mathrm{J}$ Paleopath 12:63-75.

Scheidel W, von Reden S, editors. 2002. The ancient economy. New York: Routledge.

Scheuer L, Black S. 2000. Developmental juvenile osteology. San Diego: Academic Press.

Scheuer JL, Musgrave JH, Evans P. 1980. The estimation of fetal and perinatal age from limb bone length by linear and logarithmic regression. Ann Hum Biol 7:257-265.

Scott E. 1991. Animal and infant burials in Romano-British villas: a revitalization movement. In: Garwood P, editor. Sacred and profane: proceedings of a conference on archaeology, ritual and religion, Oxford. Oxford: Oxford University Committee for Archaeology Monograph. p 115-121. 
Scott S, Duncan CJ. 1999a. Nutrition, fertility and steady-state population dynamics in a preindustrial community in Penrith, Northern England. Journal of Biosocial Science 31:505-523.

Scott S, Duncan C J. 1999b. Malnutrition, pregnancy and infant mortality: a biometric model. J Interdiscip Hist 30:37-60.

Scott S, Duncan C J. 2000. Interacting effects of nutrition and social class differentials on fertility and infant mortality in a pre-industrial population. Popul Stud 54:71-87.

Smith BH. 1991. Standards of human tooth formation and dental age assessment. In: Kelley MA, Larsen CS, editors. Advances in dental anthropology. New York: Wiley Liss. p 143168 .

Snoddy AME, Buckley HR, Halcrow SE. 2016. More than metabolic: considering the broader paleoepideiological impact of vitamin D deficiency in bioarchaeology. Am J Phys Anthropol 160:183-196.

Sparey-Green C. 2004. Living amongst the dead: from Roman eemetery to post-Roman monastic settlement at Poundbury. In: Collins R, Gerrard J, editors. Debating late Antiquity in Britain AD 300-700. Oxford: Archaeopress. p 103-112.

Stark RJ. 2014. A proposed framework for the study of paleopathological cases of subadult scurvy. Int J Paleopath 5:18-26.

Stead IM, Rigby V. 1986. Baldock: the excavation of a Roman and pre-Roman settlement, 1968-72. London: Society for the Promotion of Roman Studies.

Stuart-Macadam P. 1991. Anaemia in Roman Britain: Poundbury Camp. In: Bush H, Zvelebil M, editors. Health in past societies - biocultural interpretations of human skeletal remains in archaeological contexts. Oxford: Tempus Reparatum. p 101-113.

Taylor J. 2001. Rural society in Roman Britain. In: James S, Millett M, editors. Britons and Romans: Advancing an archaeological agenda. York: CBA Research Report 125. p 46-59.

Temkin O. 1991. Soranus’ gynecology. Baltimore: Johns Hopkins University Press.

Thacher TD, Fischer PR, Strand MA, Pettifor JM. 2006. Nutritional rickets around the world: causes and future directions. Paediatr Int Child Health 26:1-16.

Todd M. 1975. Margidunum and Ancaster. In: Rodwell W, Rowley T, editors. The 'Small Towns' of Roman Britain. Oxford: BAR British Series 15. p 211-224. 
Tyler PA, Madani G, Chaudhuri R, Wilson LF, Dick EA. 2006. The radiological appearances of thalassaemia. Clin Radiol 61:40-42.

Urnaa V, Kizuki M, Nakamuro K, Kaneko A, Inose T, Seino K, Takano T. 2006. Association of swaddling, rickets onset and bone properties in children in Ulaanbaatar, Mongolia. Public Health 120:834-840.

USDA National Nutrient Database. 2013. USDA National Nutrient Database for Standard Reference Release 26 - Nutrients: vitamin C, total ascorbic acid (mg). Available from: http://ods.od.nih.gov [accessed 07/05/2015].

Van der Veen M. 2008. Food as embodied material culture: diversity and change in plant food consumption in Roman Britain. J Roman Archaeol 21:83-109.

Van der Veen M, Livarda A, Hill A. 2007. The archaeobotany of Roman Britain: current state and identification of research priorities. Britannia 38:181-210.

Van der Veen M, Livarda A, Hill A. 2008. New plant foods in Roman Britain: dispersal and social access. Environ Archaeol 13:11-36.

Van Sleuwen BE, Engelberts AC, Boere-Boonekamp MM, Kuis W, Schulpen TWJ, L'Hoir MP. 2007. Swaddling: a systematic review. Pediatrics 120:1097-1106.

Viner L, Leech R. 1982. Bath Gate cemetery, 1969-1976. In: McWhirr A, Viner L, Wells C. Cirencester excavations II - Romano-British cemeteries at Cirencester. Cirencester: Cirencester Excavation Committee. p 69-133.

Wacher J. 1974. The towns of Roman Britain. London: Batsford.

Wagner CL, Greer FR, Section on Breastfeeding and Committee on Nutrition. 2008. Preventing rickets and vitamin D deficiency in infants, children, and adolescents. Pediatrics 122:1142-1152.

Walker PL, Bathurst RR, Richman R, Gjerdrum T, Andrushko VA. 2009. The causes of porotic hyperostosis and cribra orbitalia: a reappraisal of the iron-deficiency-anemia hypothesis. Am J Phys Anthropol 139:109-125.

Wapler U, Cruzeby E, Schultz M. 2004. Is cribra orbitalia synonymous with anemia? Analysis and interpretation of cranial pathology in Sudan. Am J Phys Anthropol 123:333339. 
Webster J. 2001. Creolizing the Roman provinces. Am J Archaeol 105:209-225.

Wells NM, Evans GW. 2003. Nearby nature - a buffer of life stress among rural children. Environ Behav 35:311-330.

Wenham LP. 1968. The Romano-British cemetery at Trentholme Drive, York. London: Ministry of Public Building and Works Archaeological Report 5.

Wenaden A, Szyszko T, Saifuddin A. 2005. Imaging of periosteal reactions associated with focal lesions of bone. Clin Radiol 60:439-456.

Weston DA. 2008. Investigating the specificity of periosteal reactions in pathology museum specimens. Am J Phys Anthropol 137:48-59.

Weston DA. 2012. Nonspecific infection in paleopathology: interpreting periosteal reactions. In: Grauer AL, editor. A companion to paleopathology. Chichester: Wiley-Blackwell. p 492512.

White R. 2014. The Wroxeter Hinterland Project: Exploring the relationship between country and town. In: Breeze DJ, editor. The impact of Rome on the British countryside. A conference organised by the Royal Archaeological Institute, Chester, 11-13 October 2013. London: Royal Archaeological Institute Supplementary Publication. p 7-11.

Whittaker CR, Garnsey P. 1997. Rural life in the later Roman Empire. In: Cameron A, Garnsey P, editors. The Cambridge ancient history 13. The late Empire, AD 337-425. Cambridge: Cambridge University Press. p 277-311.

Wileman J. 2005. Hide and seek - the archaeology of childhood. Stroud: Tempus.

Wilson P. 2011. Introduction to heritage assets - Roman settlements. London: English Heritage.

Wood JW, Milner G R, Harpending HC, Weiss KM. 1992. The osteological paradox problems of inferring prehistoric health from skeletal samples. Curr Anthropol 33:343-370.

Wood JW, Holman DJ, O’Connor KA, Ferrell RJ. 2002. Mortality models for paleodemography. In: Hoppa RD, Vaupel JW, editors. Paleodemography - age distributions from skeletal samples. Cambridge: Cambridge University Press. p 129-168. 
Zahareas MA. 2001. Contributory factors of extraneous new bone growth on the endocranial surfaces of human infant and sub-adult skeletal remains. MSc thesis. Loyola University Chicago, USA.

Table 1. Study samples by settlement type

Table 2. Age-at-death of non-adults from Roman England

Table 3. Differences in frequency of skeletal pathology and age-at-death

Table 4. Number and percent of endocranial lesions in non-adults with crania

Table 5. Crude prevalence rates of new bone formation

Table 6. Summary of probable and possible tuberculosis

Table 7. Probable and possible non-adult tuberculosis in the non-Poundbury sample

Table 8. Number and percent of haematopoietic lesions

Table 9. Number and percent of vitamin D and C deficiency 
Table 1. Study samples by settlement type

\begin{tabular}{|c|c|c|c|c|}
\hline Site & Date (AD) & Type & $\begin{array}{l}\text { Number of } \\
\text { non-adults }\end{array}$ & Site Reference \\
\hline Winchester (North, West, East) & $1-4^{\text {th }}$ century & Major Urban & 166 & Ottaway et al. (2012) \\
\hline Kingsholm, Gloucester & $2-4^{\text {th }}$ century & Major Urban & 17 & Hurst (1985), (1986) \\
\hline Gambier-Parry Lodge, Gloucester & $2-4^{\text {th }}$ century & Major Urban & 12 & Heighway (1980); Mullin (2006) \\
\hline Trentholme Drive, York & $3-4^{\text {th }}$ century & Major Urban & 24 & Wenham (1968); Ottaway (2009) \\
\hline Bath Gate, Cirencester & $4^{\text {th }}$ century & Major Urban & 64 & Viner and Leech (1982) \\
\hline Butt Road, Colchester & $4-5^{\text {th }}$ century & Major Urban & 109 & Crummy and Crossan (1993) \\
\hline Major urban total & & & 392 & \\
\hline Baldock, Hertfordshire & $2-4^{\text {th }}$ century & Minor Urban & 83 & $\begin{array}{l}\text { Stead and Rigby (1986); Burleigh } \\
\text { and Fitzpatrick-Matthews (2010) }\end{array}$ \\
\hline Queenford Farm/Mill, Oxfordshire & $3-4^{\text {th }}$ century & Minor Urban & 60 & $\begin{array}{l}\text { Durham and Rowley (1972); } \\
\text { Chambers (1987) }\end{array}$ \\
\hline Ancaster, Lincolnshire & $3-4^{\text {th }}$ century & Minor Urban & 81 & Todd (1975); Cox (1989) \\
\hline Great Casterton, Rutland & $3-4$ th century & Minor Urban & 38 & McConnell et al. (2012) \\
\hline Ashton, Northamptonshire & $4^{\text {th }}$ century & Minor Urban & 60 & Dix (1983) \\
\hline Dunstable, Bedfordshire & $3-5^{\text {th }}$ century & Minor Urban & 27 & Matthews (1981) \\
\hline \multicolumn{5}{|l|}{ Minor urban total } \\
\hline Owslebury, Hampshire & $1-4^{\text {th }}$ century & Rural & 16 & Collis (1968), (1977) \\
\hline Cannington, Somerset & $3-4^{\text {th }}$ century & Rural & 148 & Rahtz et al. (2000) \\
\hline Catsgore, Somerset & $2-5^{\text {th }}$ century & & 19 & Leech (1982) \\
\hline Bradley Hill, Somerset* & $4-5^{\text {th }}$ century & & 29 & Leech et al. (1981); Gerrard (2011) \\
\hline Rural total & & & 212 & \\
\hline Total sample & & & 953 & \\
\hline
\end{tabular}

*non-adult burials were recovered from within the settlement boundaries associated with a $4^{\text {th }}$ century AD building (Leech et al., 1981), rather than from the $5^{\text {th }}$ century AD cemetery (Gerrard, 2011) 
Table 2. Age-at-death of non-adults from Roman England

\begin{tabular}{lllllllll}
\hline & \multicolumn{2}{l}{ Poundbury Camp } & \multicolumn{2}{l}{ Major urban } & \multicolumn{2}{l}{ Minor urban } & \multicolumn{2}{l}{ Rural } \\
\hline Age (yrs) & $n$ & $\%$ & $n$ & $\%$ & $n$ & $\%$ & $n$ & $\%$ \\
Perinate & 55 & 15.1 & 81 & 20.6 & 70 & 20.1 & 43 & 20.3 \\
$0.0-1.0$ & 87 & 23.9 & 65 & 16.6 & 77 & 22.1 & 66 & 31.3 \\
$1.1-2.5$ & 46 & 12.6 & 42 & 10.7 & 56 & 16.1 & 24 & 11.3 \\
$2.6-6.5$ & 55 & 15.1 & 62 & 15.8 & 68 & 19.5 & 32 & 15.1 \\
$6.6-10.5$ & 41 & 11.3 & 44 & 11.2 & 30 & 8.6 & 11 & 5.2 \\
$10.6-14.5$ & 34 & 9.3 & 48 & 12.2 & 29 & 8.3 & 20 & 9.4 \\
$14.6-17.0$ & 13 & 3.6 & 28 & 7.1 & 11 & 3.2 & 15 & 7.1 \\
Non-adult & 33 & 9.1 & 22 & 5.6 & 8 & 2.3 & 1 & 0.5 \\
Total & $\mathbf{3 6 4}$ & & $\mathbf{3 9 2}$ & & $\mathbf{3 4 9}$ & & $\mathbf{2 1 2}$ & \\
\hline
\end{tabular}

$\%$ rounded percentage of site total for each age group

Table 3. Differences in frequency of skeletal pathology and age-at-death

\begin{tabular}{llll}
\hline & $\mathbf{0 - 5}$ years & $\mathbf{6 - 1 7}$ years & $\boldsymbol{X}^{2}$ \\
\hline $\begin{array}{l}\text { Site type } \\
\text { Poundbury Camp }\end{array}$ & $N$ & $N$ & \\
n skeletal pathology & $\mathbf{2 4 2}$ & $\mathbf{9 2}$ & \\
\% skeletal pathology & 60 & 19 & 0.71 \\
Major urban & 24.8 & 20.7 & \\
n skeletal pathology & $\mathbf{2 3 4}$ & $\mathbf{1 3 6}$ & \\
\% skeletal pathology & 50 & 50 & 10.26 \\
Minor urban & 21.4 & 36.8 & \\
n skeletal pathology & & & \\
\% skeletal pathology & $\mathbf{2 5 6}$ & $\mathbf{8 5}$ & $16.94^{*}$ \\
& 70 & 44 & \\
Rural & 27.3 & 51.8 & \\
n skeletal pathology & $\mathbf{1 6 2}$ & $\mathbf{4 9}$ & \\
\% skeletal pathology & 47 & 29 & \\
\hline *p $<0.001$, d.f. $=2$ & 29.0 & 59.2 & \\
& & &
\end{tabular}


Table 4. Number and percent for endocranial lesions in non-adults with crania

\begin{tabular}{lllllllll}
\hline & \multicolumn{2}{l}{ Poundbury Camp } & \multicolumn{2}{l}{ Major urban } & \multicolumn{2}{l}{ Minor urban } & \multicolumn{2}{l}{ Rural } \\
\hline Age (yrs) & Observed & Affected $n / \%$ & Observed & Affected $n / \%$ & Observed & Affected $n / \%$ & Observed & Affected $n / \%$ \\
Perinate & 33 & $1 / 3.0$ & 61 & $5 / 8.2$ & 43 & $1 / 2.3$ & 21 & $1 / 4.8$ \\
$0-1.0$ & 50 & $3 / 6.0$ & 4 & 0 & 19 & $3 / 15.8$ & 9 & 0 \\
$1.1-2.5$ & 37 & $4 / 10.8$ & 37 & $4 / 10.8$ & 54 & $11 / 20.4$ & 23 & $3 / 13.0$ \\
$2.6-6.5$ & 47 & $2 / 4.3$ & 48 & 0 & 57 & $8 / 14.0$ & 22 & $3 / 13.6$ \\
$6.6-10.5$ & 34 & $1 / 2.9$ & 33 & $2 / 6.1$ & 23 & $5 / 21.7$ & 7 & $1 / 14.3$ \\
$10.6-14.5$ & 29 & $1 / 3.4$ & 41 & 0 & 23 & $1 / 4.4$ & 17 & $2 / 11.8$ \\
$14.6-17.0$ & 13 & 0 & 22 & $1 / 4.6$ & 8 & $2 / 25.0$ & 13 & $1 / 7.7$ \\
Non-adult & 4 & $2 / 50$ & 11 & 0 & 5 & 0 & 1 & 0 \\
Total & $\mathbf{2 4 7}$ & $\mathbf{1 4 / 5 . 7}$ & $\mathbf{1 9 6}$ & $\mathbf{7 / 3 . 6}$ & $\mathbf{1 9 2}$ & $\mathbf{3 0 / 1 5 . 9}$ & $\mathbf{9 2}$ & $\mathbf{1 0} / \mathbf{1 0 . 9}$ \\
\hline
\end{tabular}

$\%$ rounded percentage of site total for each age group

Table 5. Number and percent crude prevalence rates of new bone formation

\begin{tabular}{|c|c|c|c|c|c|c|c|c|}
\hline & Poundbur & Camp & Major urb & an & Minor urb & & Rural & \\
\hline Age (yrs) & Observed & Affected $n / \%$ & Observed & Affected $n / \%$ & Observed & Affected $n / \%$ & Observed & Affected $n / \%$ \\
\hline $0.6-1.0$ & - & - & 5 & & 27 & $1 / 7.4$ & 14 & 0 \\
\hline $1.1-2.5$ & 27 & 0 & 27 & $2 / 7.4$ & 49 & $2 / 4.1$ & 19 & 0 \\
\hline $2.6-6.5$ & 40 & $1 / 2.5$ & & $4 / 8.7$ & 62 & $7 / 11.3$ & 25 & $1 / 4.0$ \\
\hline $6.6-10.5$ & 32 & $1 / 3.1$ & 37) & $5 / 13.5$ & 25 & $2 / 8.0$ & 7 & $1 / 14.3$ \\
\hline $10.6-14.5$ & 30 & 0 & 36 & $5 / 13.9$ & 27 & $2 / 7.4$ & 17 & $1 / 5.9$ \\
\hline $14.6-17.0$ & 11 & & 22 & $2 / 9.1$ & 11 & 0 & 13 & $2 / 15.4$ \\
\hline $\begin{array}{l}\text { Non- } \\
\text { adult }\end{array}$ & 3 & & 9 & 0 & 3 & 0 & 0 & 0 \\
\hline Total & 143 & $4 / 2.8$ & 182 & $18 / 9.9$ & 204 & $14 / 6.9$ & 95 & $5 / 5.3$ \\
\hline Active & 143 & $3 / 2.1$ & 182 & $9 / 4.9$ & 204 & $8 / 3.9$ & 95 & $2 / 2.1$ \\
\hline Healed & 143 & $1 / 0.7$ & 182 & $7 / 3.8$ & 204 & $4 / 2.0$ & 95 & $2 / 2.1$ \\
\hline
\end{tabular}

$\%$ rounded percentage of site total for each age group 
Table 6. Summary of probable or possible tuberculosis and pulmonary infection

\begin{tabular}{lllll}
\hline & Total & Probable tuberculosis & Possible tuberculosis & Pulmonary infection \\
\hline \multirow{2}{*}{ Poundbury Camp } & Observed & Affected $n / \%$ & Affected $n / \%$ & Affected $n / \%$ \\
Major urban & 165 & $2 / 1.2$ & $5 / 3.0$ & $3 / 1.8$ \\
Minor urban & 161 & $2 / 1.2$ & $1 / 0.6$ & $8 / 5.0$ \\
Rural & 157 & $1 / 0.6$ & $1 / 0.6$ & $2 / 1.3$ \\
Total & 04 & 0 & $1 / 1.2$ & 0 \\
\hline \% rounded percentage of site total & $\mathbf{5 / 0 . 9}$ & $\mathbf{8 / 1 . 4}$ & $\mathbf{1 3 / 2 . 3}$ \\
\hline
\end{tabular}

$\%$ rounded percentage of site total 
Table 7. Probable and possible tuberculosis in the non-Poundbury non-adults

\begin{tabular}{|c|c|c|c|c|}
\hline Site/skeleton & $\begin{array}{l}\text { Age } \\
\text { range }\end{array}$ & Bones present & Lesions observed & Diagnosis \\
\hline $\begin{array}{l}\text { Butt Road, } \\
\text { Colchester/376 }\end{array}$ & $\begin{array}{l}10.6- \\
14.5\end{array}$ & $\begin{array}{l}\text { Skull, teeth, ribs, } \\
\text { spine, pelvis, } \\
\text { long bones, } \\
\text { hands/feet }\end{array}$ & $\begin{array}{l}\text { Lytic lesions and minimal new bone formation on visceral } \\
\text { aspect of ribs. Lytic foci on vertebral bodies of L1-L5. S1 } \\
\text { with lytic lesion on anterior aspect of body. MC1 with } \\
\text { possible dactylitis. Iliac blades with resorptive foci on } \\
\text { cortex both medio-anteriorly and adjacent to auricular } \\
\text { surface bilaterally with localised new bone formation. }\end{array}$ & $\begin{array}{l}\text { Probable pulmonary } \\
\text { TB, with possible } \\
\text { gastro-intestinal } \\
\text { origin }\end{array}$ \\
\hline $\begin{array}{l}\text { Butt Road, } \\
\text { Colchester/672 }\end{array}$ & $\begin{array}{l}2.6- \\
6.5\end{array}$ & $\begin{array}{l}\text { Skull, teeth, ribs, } \\
\text { spine, pelvis, } \\
\text { long bones }\end{array}$ & $\begin{array}{l}\text { Localised healed new bone formation on pleural aspect of } \\
\text { rib heads, some with lytic foci in new bone deposits. One } \\
\text { right rib head with large lytic lesion on vertebral aspect } \\
\text { with sclerotic margins and minimal new bone formation. } \\
\text { Pott's disease affecting T1-T3 with fusion evident. }\end{array}$ & $\begin{array}{l}\text { Probable pulmonary } \\
\text { TB }\end{array}$ \\
\hline Ashton/126 & $\begin{array}{l}2.6- \\
6.5\end{array}$ & $\begin{array}{l}\text { Skull, teeth, ribs, } \\
\text { spine, pelvis, } \\
\text { long bones, } \\
\text { hands/feet }\end{array}$ & $\begin{array}{l}\text { Parietal endocranial lesions. Healing new bone formation } \\
\text { on the tibial shafts bilaterally. Widespread active new bone } \\
\text { formation on medial aspects of iliac blades. Destructive } \\
\text { resorption on sacral bodies and L5. S1 with large lytic } \\
\text { lesion on left lateral portion of body. Large lytic focus on } \\
\text { superior aspect of L5 vertebral body. }\end{array}$ & $\begin{array}{l}\text { Probable pulmonary } \\
\text { TB, with possible } \\
\text { gastro-intestinal } \\
\text { origin }\end{array}$ \\
\hline $\begin{array}{l}\text { Trentholme } \\
\text { Drive, York/31 }\end{array}$ & $\begin{array}{l}6.6- \\
10.5\end{array}$ & $\begin{array}{l}\text { Mandible, teeth, } \\
\text { ribs, spine, } \\
\text { pelvis, long } \\
\text { bones, } \\
\text { hands/feet }\end{array}$ & $\begin{array}{l}\text { Left ribs with prominent new bone formation on visceral } \\
\text { aspect with localised lytic foci in new bone deposits. } \\
\text { Widespread new bone formation on tibial shaft and } \\
\text { ealcanei. Right fibula with suppurative osteomyelitis. }\end{array}$ & $\begin{array}{l}\text { Possible pulmonary } \\
\text { TB/pulmonary } \\
\text { infection }\end{array}$ \\
\hline Ancaster/55 & $\begin{array}{l}2.5- \\
6.5\end{array}$ & $\begin{array}{l}\text { Skull, teeth, ribs, } \\
\text { spine, pelvis, } \\
\text { long bones, }\end{array}$ & $\begin{array}{l}\text { Parietal endocranial lesions. Ribs with new bone formation } \\
\text { on pleural aspect, with localised lytic lesion. Ulnae, } \\
\text { femora, tibiae and fibulae with widespread new bone } \\
\text { formation. }\end{array}$ & $\begin{array}{l}\text { Possible pulmonary } \\
\text { TB/pulmonary } \\
\text { infection }\end{array}$ \\
\hline Cannington/51b & $\begin{array}{l}14.5- \\
17.0\end{array}$ & $\begin{array}{l}\text { Skull, teeth, ribs, } \\
\text { spine, pelvis, } \\
\text { long bones, } \\
\text { hands/feet }\end{array}$ & $\begin{array}{l}\text { Parietal endocranial lesions. Ribs with new bone formation } \\
\text { and lytic lesions within new bone deposits. Widespread } \\
\text { active new bone formation on femoral and tibial shafts. }\end{array}$ & $\begin{array}{l}\text { Possible pulmonary } \\
\text { TB/pulmonary } \\
\text { infection }\end{array}$ \\
\hline
\end{tabular}


Table 8. Number and percent true prevalence rates for cribra orbitalia and porotic hyperostosis

\begin{tabular}{|c|c|c|c|c|c|c|c|c|}
\hline & \multicolumn{2}{|c|}{ Poundbury Camp } & \multicolumn{2}{|c|}{ Major urban } & \multicolumn{2}{|c|}{ Minor urban } & \multicolumn{2}{|l|}{ Rural } \\
\hline \multicolumn{9}{|c|}{ Cribra orbitalia } \\
\hline Age (yrs) & Observed & Affected $n / \%$ & Observed & Affected $n / \%$ & Observed & Affected $n / \%$ & Observed & Affected $n / \%$ \\
\hline Perinate & 26 & 0 & 54 & 0 & 37 & 0 & 19 & 0 \\
\hline $0.0-1.0$ & 36 & $2 / 5.6$ & 33 & 0 & 26 & 0 & 26 & $1 / 3.8$ \\
\hline $1.1-2.5$ & 45 & $14 / 31.1$ & 30 & $4 / 13.3$ & 37 & $6 / 16.2$ & 14 & $9 / 64.3$ \\
\hline $2.6-6.5$ & 56 & $19 / 33.9$ & 32 & $10 / 31.3$ & 42 & $19 / 45.2$ & & $6 / 46.2$ \\
\hline $6.6-10.5$ & 52 & $21 / 40.4$ & 24 & $5 / 20.8$ & 18 & $7 / 38.9$ & & $4 / 66.7$ \\
\hline $10.6-14.5$ & 44 & $17 / 38.6$ & 30 & $10 / 33.3$ & 20 & $6 / 30.0$ & & $3 / 25.0$ \\
\hline $14.6-17.0$ & 11 & $3 / 27.3$ & 18 & $6 / 33.3$ & 6 & $2 / 33.3$ & 11 & $5 / 45.5$ \\
\hline Non-adult & 1 & $1 / 100$ & 5 & $1 / 20.0$ & 0 & 0 & 0 & 0 \\
\hline Total & 200 & 77/38.5 & 223 & $36 / 16.1$ & 186 & $40 / 21.5$ & 101 & $28 / 27.7$ \\
\hline Active & 200 & $42 / 21.0$ & 223 & $24 / 10.8$ & 1 & $29 / 15.6$ & 101 & $25 / 24.8$ \\
\hline Healed & 200 & $25 / 12.5$ & 223 & $12 / 5.4$ & & $10 / 5.4$ & 101 & $1 / 0.9$ \\
\hline \multicolumn{9}{|c|}{ Porotic hyperostosis } \\
\hline Age (yrs) & Observed & Affected $n / \%$ & Observed & Affe & Observed & Affected $n / \%$ & Observed & Affected $n / \%$ \\
\hline Perinate & 47 & 0 & 51 & 0 & 37 & 0 & 20 & 0 \\
\hline $0.0-1.0$ & 78 & $9 / 11.5$ & 42 & & 36 & $1 / 2.8$ & 37 & $1 / 2.7$ \\
\hline $1.1-2.5$ & 40 & $6 / 15.0$ & & $2 / 5.7$ & 50 & $2 / 4.0$ & 18 & $4 / 22.2$ \\
\hline $2.6-6.5$ & 52 & $3 / 57.7$ & 45 & 0 & 54 & 0 & 20 & 0 \\
\hline $6.6-10.5$ & 36 & $2 / 5.6$ & - & 0 & 22 & 0 & 6 & 0 \\
\hline $10.6-14.5$ & 33 & 0 & 41 & $1 / 2.4$ & 23 & 0 & 15 & 0 \\
\hline $14.6-17.0$ & 0 & 0 & 20 & 0 & 8 & 0 & 13 & $2 / 15.4$ \\
\hline Non-adult & 15 & & 11 & $1 / 9.1$ & 5 & 0 & 1 & $1 / 100$ \\
\hline Total & 302 & & 278 & $4 / 1.4$ & 235 & $3 / 2.8$ & 130 & $8 / 6.2$ \\
\hline
\end{tabular}

$\%$ rounded percentage of site total for each age group 
Table 9. Number and percent prevalence rates for vitamin D and C deficiency

\begin{tabular}{|c|c|c|c|c|c|c|c|c|}
\hline & \multicolumn{2}{|c|}{ Poundbury Camp } & \multicolumn{2}{|c|}{ Major urban } & \multicolumn{2}{|c|}{ Minor urban } & \multicolumn{2}{|l|}{ Rural } \\
\hline \multicolumn{9}{|c|}{ Vitamin D deficiency } \\
\hline Age (yrs) & Observed & Affected $n / \%$ & Observed & Affected $n / \%$ & Observed & Affected $n / \%$ & Observed & Affected $n / \%$ \\
\hline Perinate & 48 & 0 & 81 & 0 & 66 & 0 & 41 & 0 \\
\hline $0.0-1.0$ & 48 & $9 / 18.8$ & 58 & $4 / 6.9$ & 64 & $7 / 10.9$ & 60 & $3 / 5.0$ \\
\hline $1.1-2.5$ & 37 & $3 / 8.1$ & 40 & $3 / 7.5$ & 56 & $2 / 3.6$ & & $2 / 8.3$ \\
\hline $2.6-6.5$ & 40 & 0 & 60 & $1 / 1.7$ & 67 & $1 / 1.5$ & & 0 \\
\hline $6.6-10.5$ & 30 & 0 & 44 & 0 & 28 & $1 / 3.6$ & 11 & 0 \\
\hline $10.6-14.5$ & 29 & 0 & 47 & 0 & 28 & 0 & 20 & 0 \\
\hline $14.6-17.0$ & 11 & 0 & 28 & $1 / 3.6$ & 11 & 0 & 14 & 0 \\
\hline Non-adult & 5 & 0 & 20 & 0 & 7 & 0 & 1 & 0 \\
\hline Total & 248 & $12 / 4.8$ & 378 & $9 / 2.4$ & & $11 / 3.4$ & 202 & $5 / 2.5$ \\
\hline \multicolumn{9}{|c|}{ Vitamin $\mathrm{C}$ deficiency } \\
\hline Age (yrs) & Observed & Affected $n / \%$ & Observed & Affected $n / \%$ & Observed & Affected $n / \%$ & Observed & Affected $n / \%$ \\
\hline Perinate & 48 & 0 & 81 & & 66 & 0 & 41 & 0 \\
\hline $0.0-1.0$ & 48 & $3 / 6.3$ & & $4 / 6.9$ & 64 & $6 / 9.4$ & 60 & $4 / 6.7$ \\
\hline $1.1-2.5$ & 37 & $4 / 10.8$ & & 0 & 56 & $1 / 1.8$ & 24 & $3 / 12.5$ \\
\hline $2.6-6.5$ & 40 & $2 / 5.0$ & 60 & $2 / 3.3$ & 67 & $1 / 1.5$ & 31 & $2 / 6.5$ \\
\hline $6.6-10.5$ & 30 & & 44 & 0 & 28 & 0 & 11 & $1 / 9.1$ \\
\hline $10.6-14.5$ & 29 & & 47 & 0 & 28 & 0 & 20 & $2 / 10.0$ \\
\hline $14.6-17.0$ & 11 & 0 & 28 & $1 / 3.6$ & 11 & 0 & 14 & 0 \\
\hline Non-adult & 5 & $1 / 20.0$ & 20 & 0 & 7 & 0 & 1 & 0 \\
\hline Total & 248 & $12 / 4.8$ & 378 & 7/1.9 & 327 & $8 / 2.4$ & 202 & $12 / 5.9$ \\
\hline
\end{tabular}

$\%$ rounded percentage of site total for each age group 
Figure 1. Location of sites (black: major urban; dark grey: minor urban; light grey: rural).

Figure 2. Age-at-death at Poundbury Camp and non-Poundbury sites.

Figure 3. Probable tuberculosis. a, new bone formation on the medial aspect of the right ilium; $b$, left rib inferio-medial with resorption and lytic lesion, also new bone formation on visceral aspect; c, S1 with lytic focus on the inferior margin of vertebral body; $d$, T5 left supero-lateral: resorptive focus on anterior vertebral body (arrow); e, MC1 with probable dactylitis. From Butt Road, Colchester, skeleton 376 (with kind permission from Colchester and Ipswich Museums).

Figure 4. Probable tuberculosis. Left lateral (a) and right lateral (c): destruction of the vertebral body of T2, and fusion of T2 and T3 at the left pedicle and lamina indicative of Pott's Disease; $b$, right rib inferiorly with new bone formation and lytic foci in sub-periosteal new bone, $\mathrm{d}$, right rib inferiorly with large circular lytic lesion on the vertebral aspect of head. From Butt Road, Colchester, skeleton 672 (with kind permission from Colchester and Ipswich Museums).

Figure 5. Probable tuberculosis. a, Type 4 endocranial lesion on parietal fragment; b, widespread periosteal new bone formation on medial aspect of right ilium; c, L5 superiorly with eroded and resorptive destruction of vertebral body (arrows); d, S1 superiorly with circular lytic lesion (arrow); e, S1 anteriorly with destruction of the anterior margins of sacral body. From Ashton, skeleton 126 (with kind permission from Vivacity Peterborough Museum and Art Gallery).

Figure 6 . True prevalence rates of cribra orbitalia by age group.

Figure 7. Vitamin D deficiency in Romano-British non-adults.

Figure 8. Vitamin C deficiency by age group. 


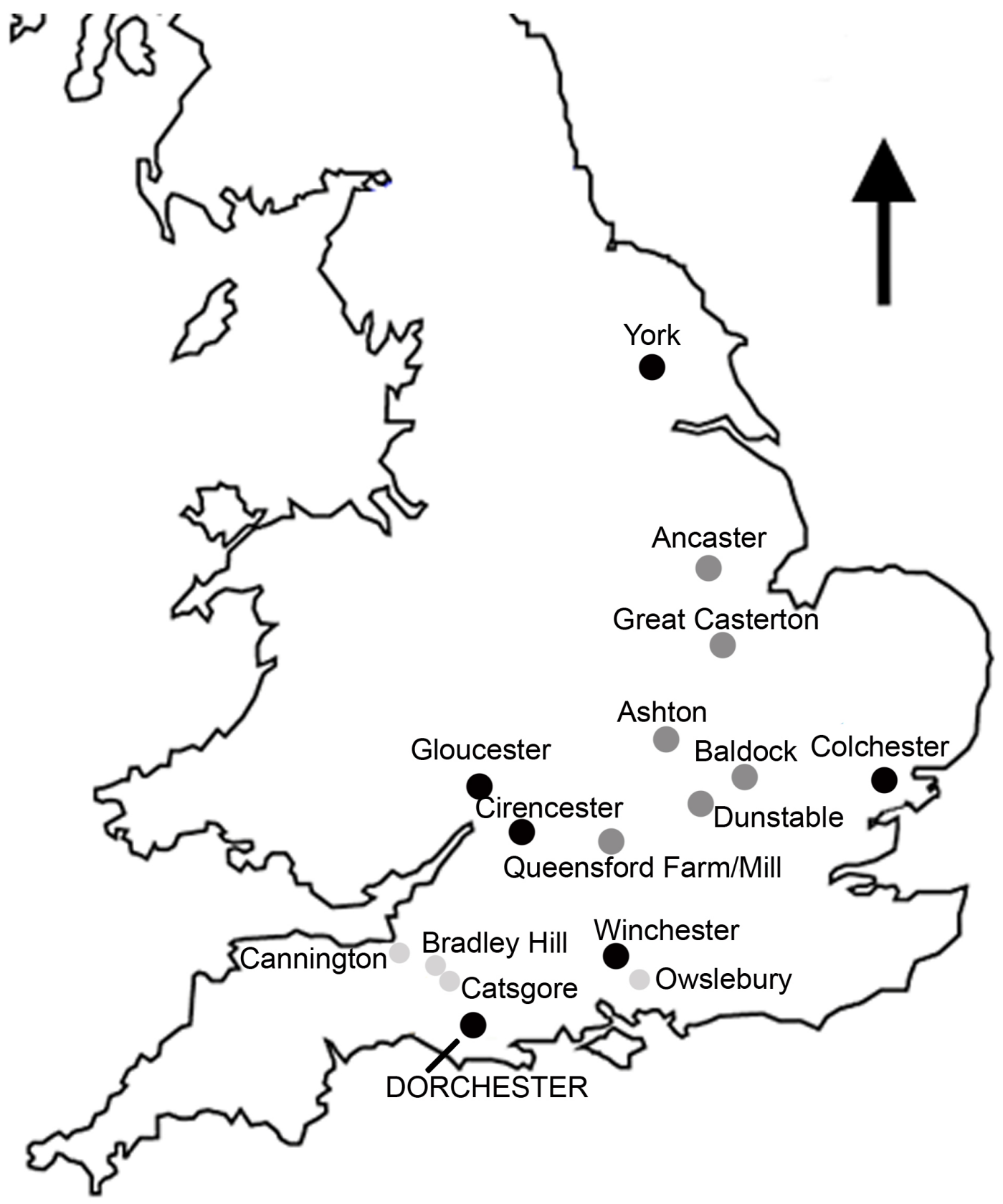

Figure 1. Location of sites (black: major urban; dark grey: minor urban; light grey: rural). 


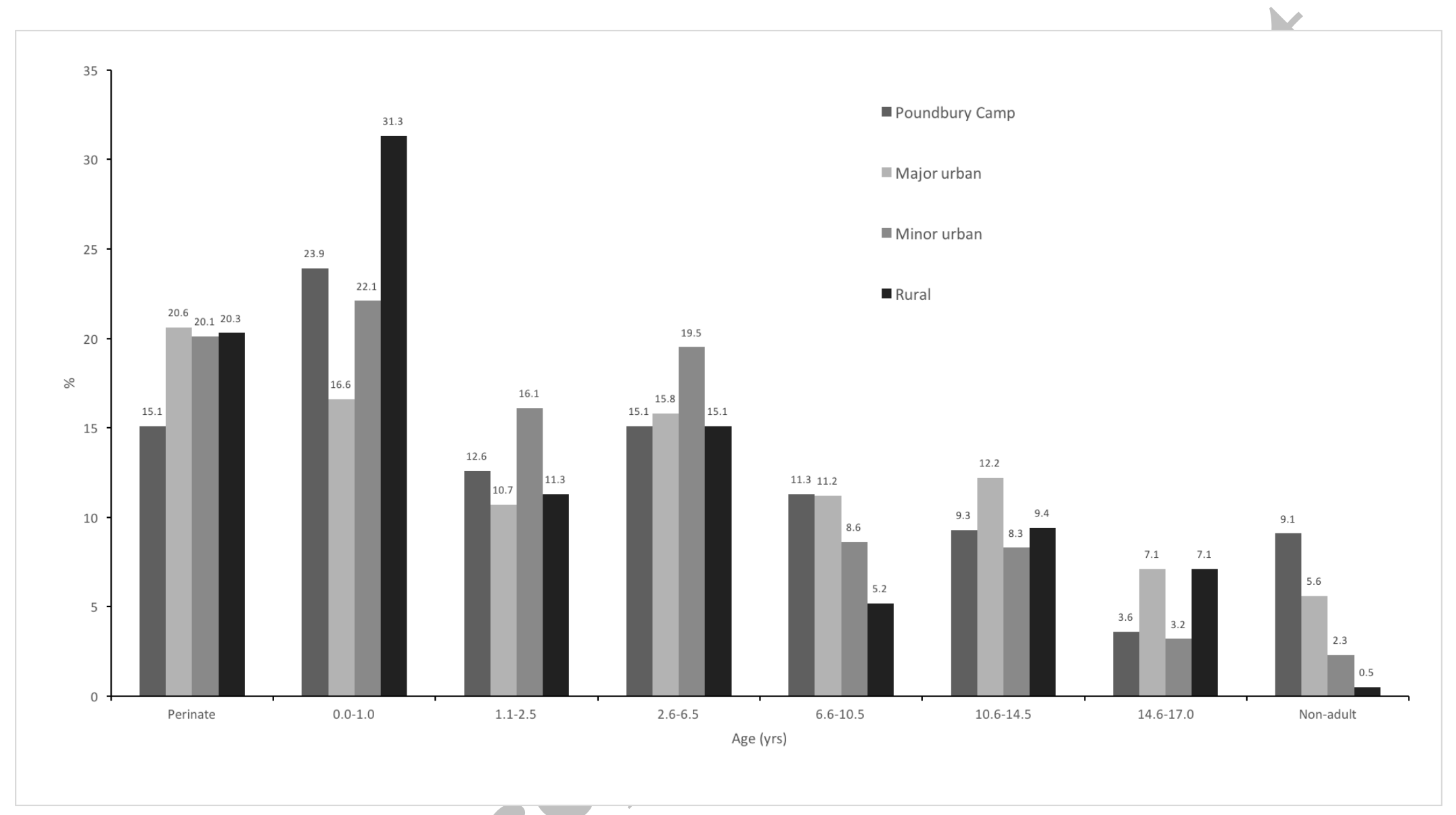

Figure 2. Age-at-death at Poundbury Camp and non-Poundbury sites. 

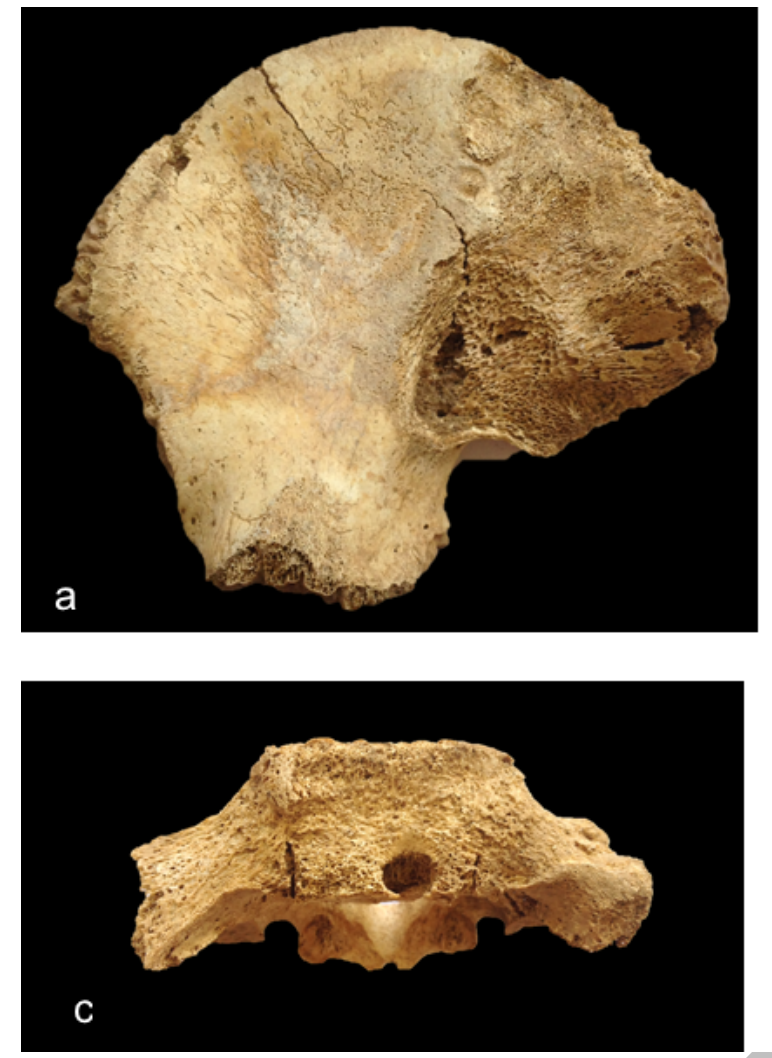
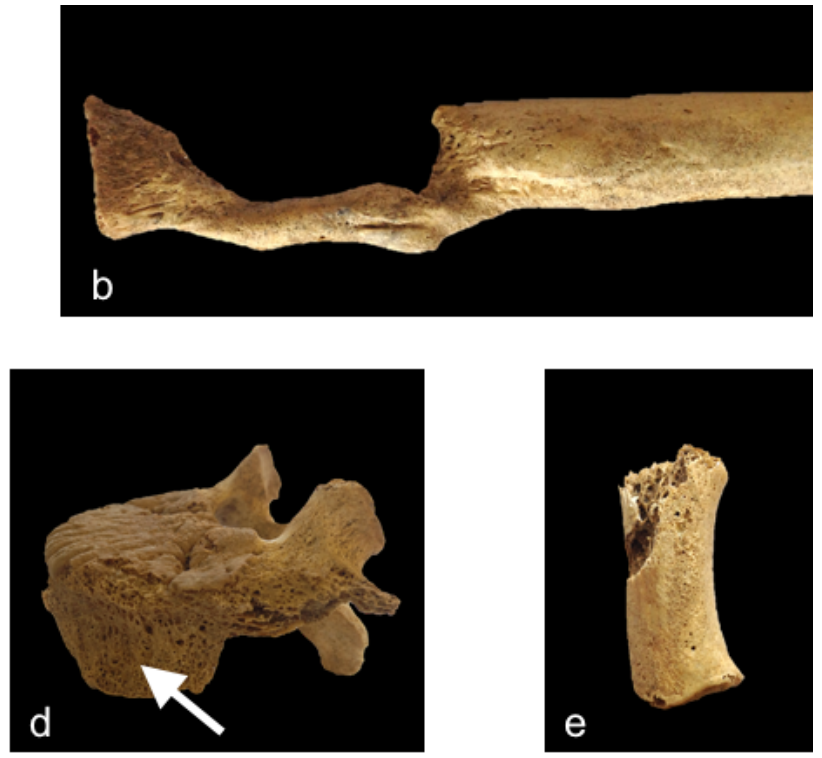

e

Figure 3. Probable tuberculosis. a, new bone formation on the medial aspect of the right ilium; b, left rib inferio-medial with resorption and lytic lesion, also new bone formation on visceral aspect; c, S1 with lytic focus on the inferior margin of vertebral body; $d$, T5 left supero-lateral: resorptive focus on anterior vertebral body (arrow); e, MC1 with probable dactylitis. From Butt Road, Colchester, skeleton 376 (with kind permission from Colchester and Ipswich Museums). 

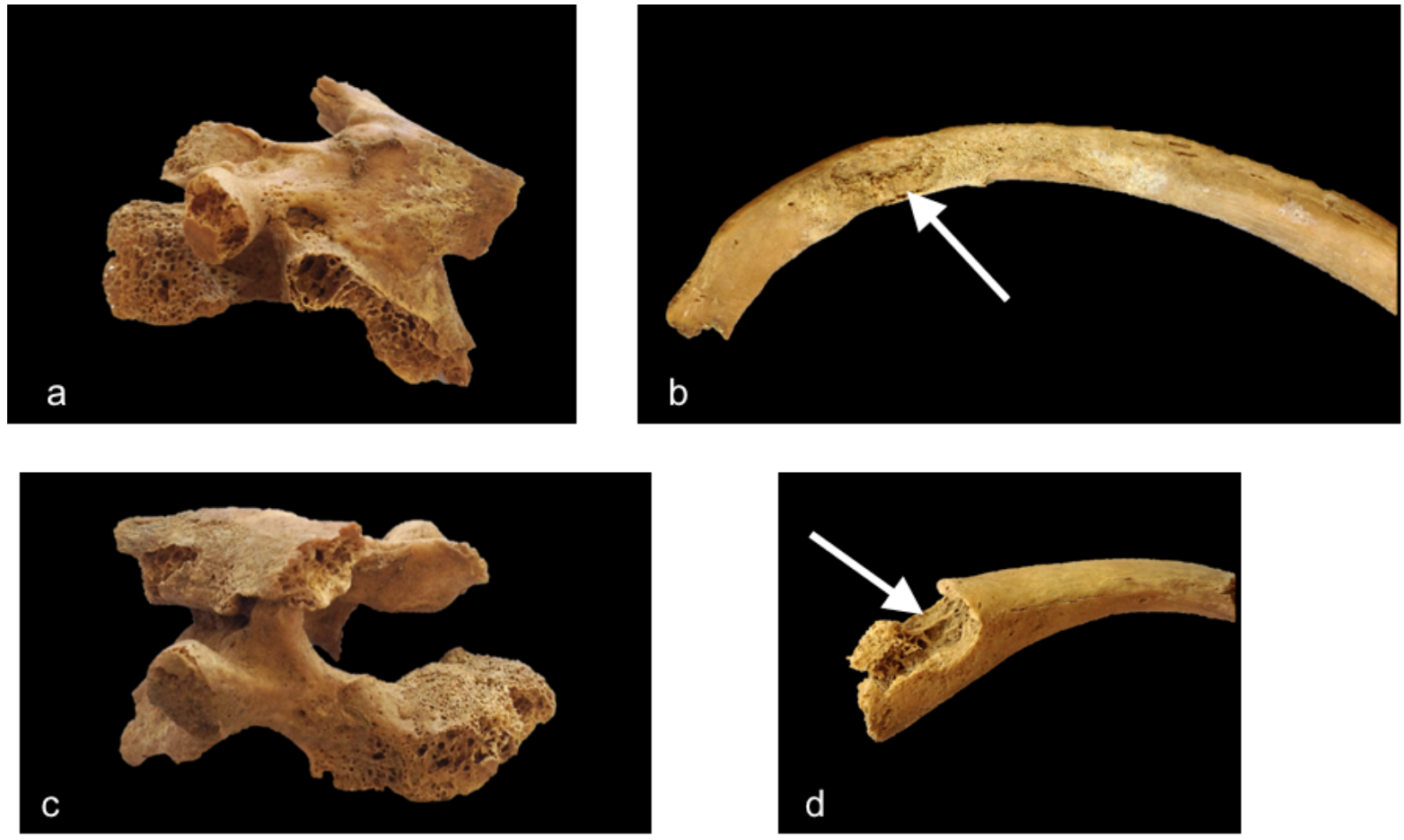

Figure 4. Probable tuberculosis. Left lateral (a) and right lateral (c): destruction of the vertebral body of T2, and fusion of T2 and T3 at the left pedicle and lamina indicative of Pott's Disease; b, right rib inferiorly with new bone formation and lytic foci in sub-periosteal new bone; $\mathrm{d}$, right rib inferiorly with large circular lytic lesion on the vertebral aspect of head. From Butt Road, Colchester, skeleton 672 (with kind permission from Colchester and Ipswich Museums). 

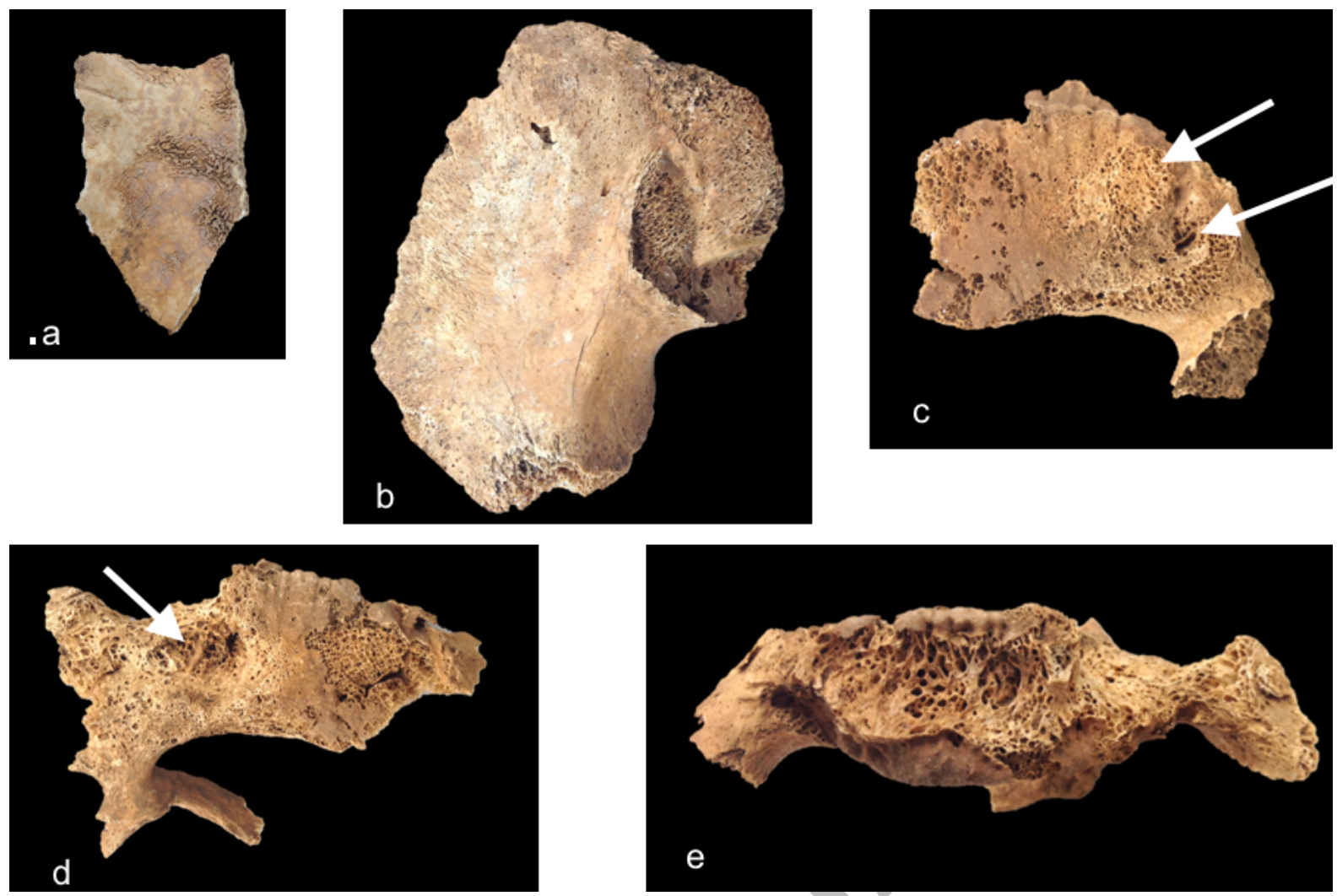

Figure 5. Probable tuberculosis. a, Type 4 endocranial lesion on parietal fragment; $b$, widespread periosteal new bone formation on medial aspect of right ilium; c, L5 superiorly with eroded and resorptive destruction of vertebral body (arrows); d, S1 superiorly with circular lytic lesion (arrow); e, S1 anteriorly with destruction of the anterior margins of sacral body. From Ashton, skeleton 126 (with kind permission from Vivacity Peterborough Museum and Art Gallery). 


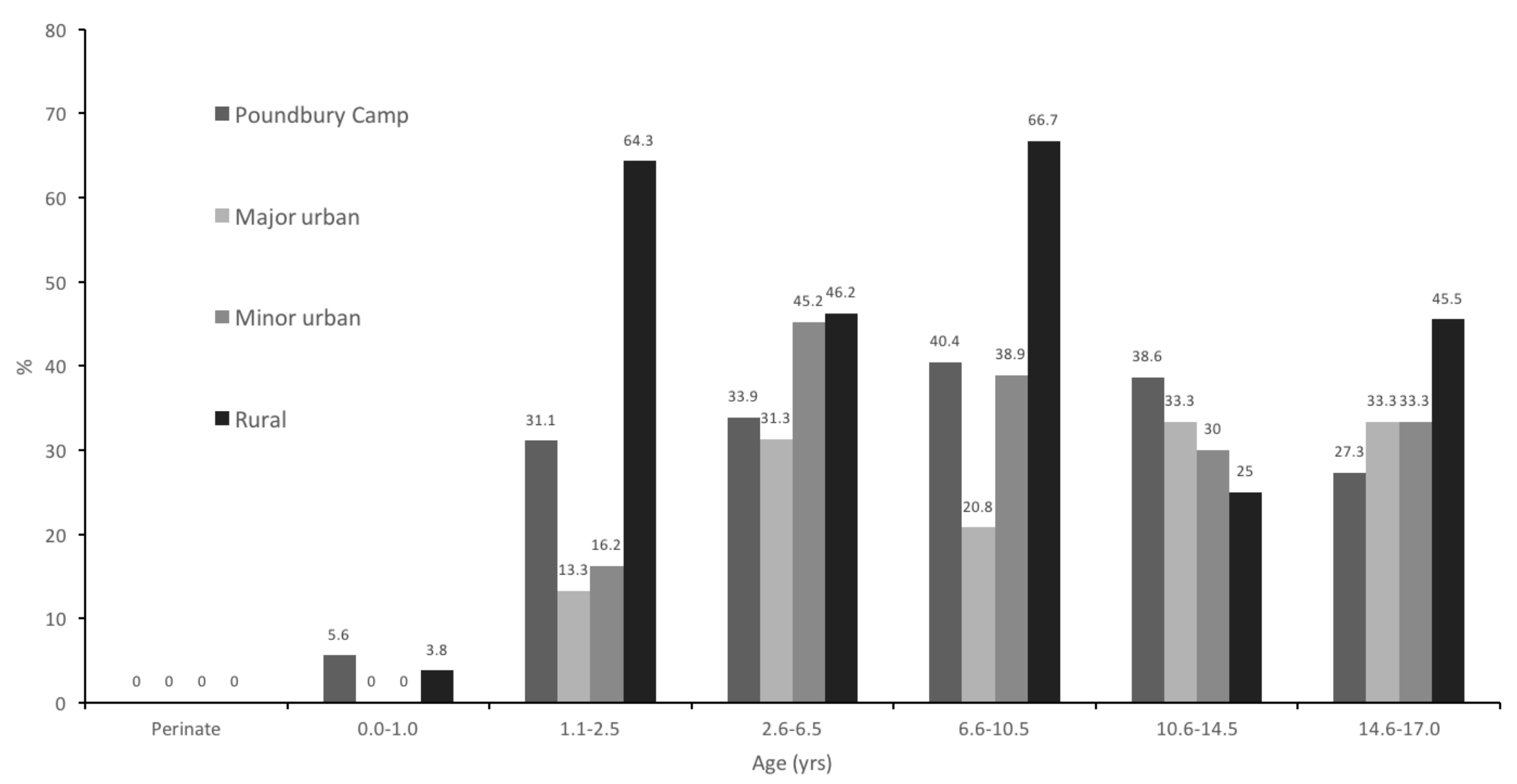

Figure 6. True prevalence rates of cribra orbitalia by age group. 


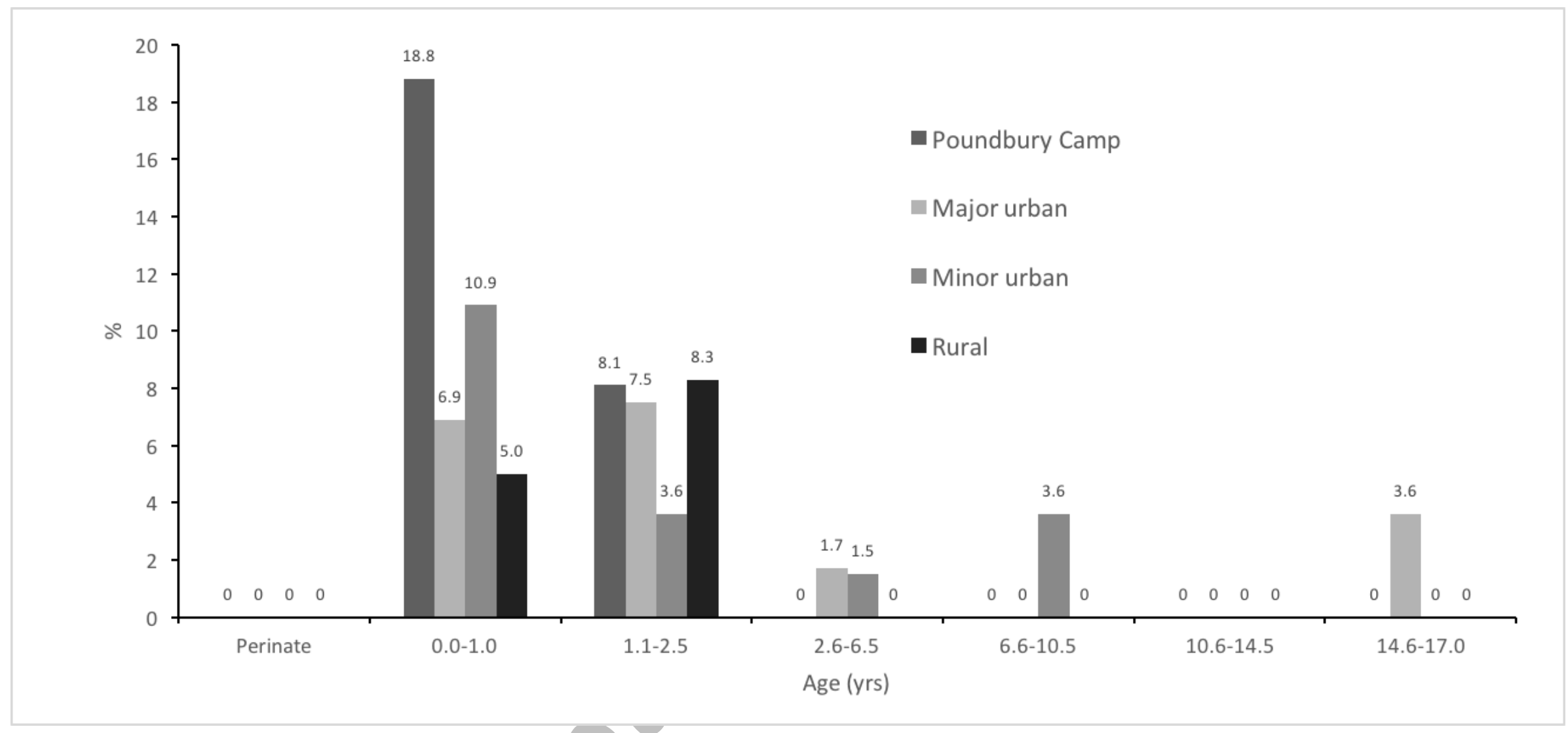

Figure 7. Vitamin D deficiency in Romano-British non-adults. 


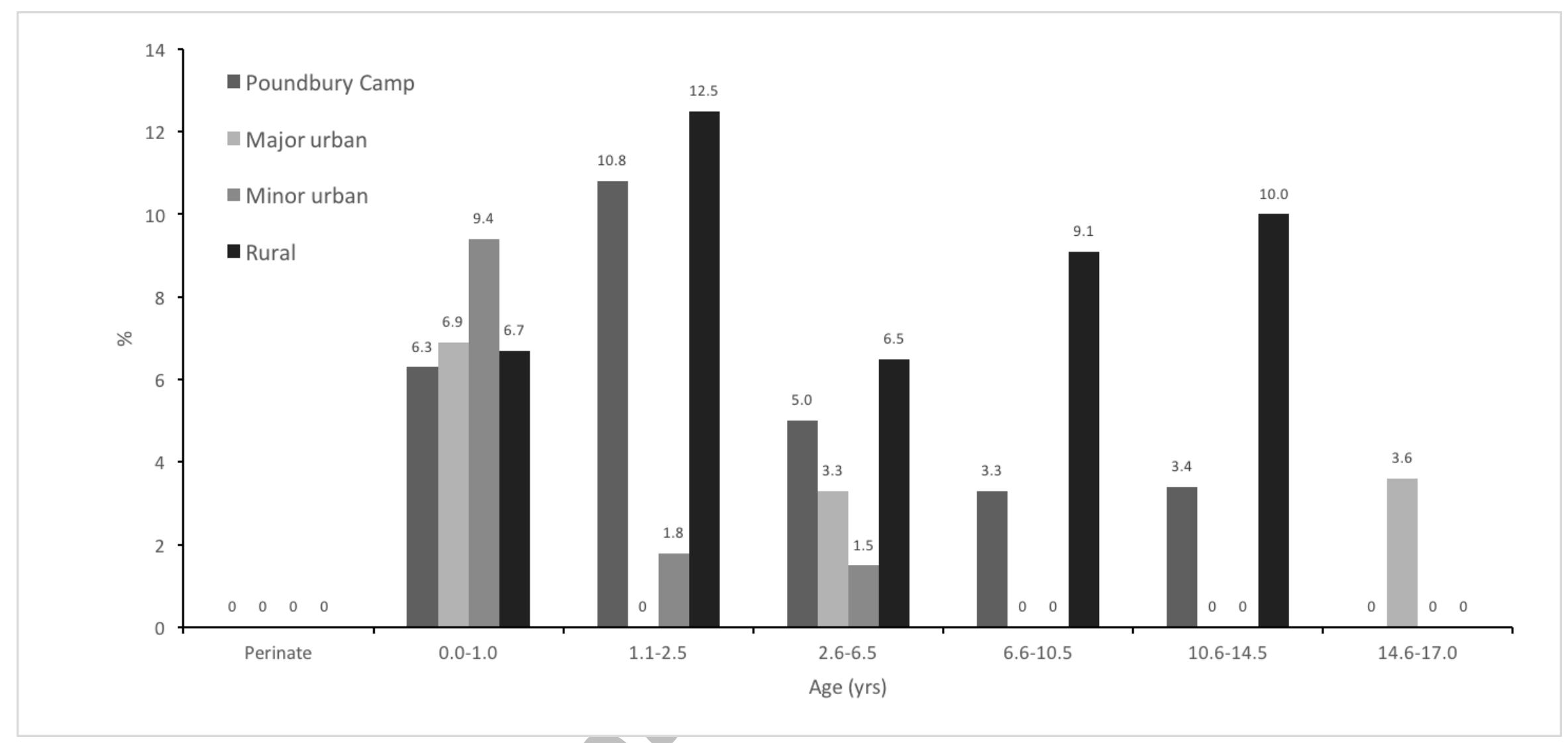

Figure 8. Vitamin C deficiency by age group. 